\title{
DISKURSUS TASAWUF NUSANTARA DI MEKAH: RESPONS MUKHTĀR 'AṬ̂̄RID AL-BUGHŪRI TERHADAP AJARAN MARTABAT TUJUH
}

\author{
THE DISCOURSE OF MALAY-INDONESIAN \\ SUFISM IN MECCA: A RESPONSE OF MUKHTĀR \\ 'ATATRID OF BOGOR TOWARDS THE DOCTRINE \\ OF SEVEN GRADES
}

\author{
Jajang A. Rohmana \\ Universitas Islam Negeri Sunan Gunung Djati Bandung Indonesia \\ jajangarohmana@uinsgd.ac.id
}

DOI: $10.31291 /$ jlk.v19i1.923

Diterima: 15 Maret 2021; Direvisi: 05 Juni 2021; Diterbitkan: 30 Juni 2021

\begin{abstract}
This study focuses on the issue of Nusantara Sufism discourse in Mecca at the beginning of the 20th century. The main object is the response of Mukhtār 'Atāirid al-Bughīrī (1862-1930), a Sundanese cleric who taught in Mecca, to the concept of the dignity of the seven. He put it in two Sundanese books printed in Egypt, Kifāyah al-Mubtadi'in and Hidāyah alMubtadi'in. Through a social history approach, the results of the study show that Mukhtār 'Atāarid's response reflects the interests of Sunni orthodoxy in the field of Sufism which is based on sharia. This view tends to reject the deviation of the teachings of the seven dignity in the archipelago which he considers heterodox and deviant. Meanwhile, in the case of the doctrine of the unity of existence (tauhīd al-wujūd) Ibn 'Arab, al-Jilī and al-Burhānfūrī, Mukhtār 'Ațārid seems to correct people's misconceptions about his teachings. Mukhtār 'Ațārid al-Bughūrī recommends being kind to his teachings because he is believed to be an expert on the true nature and by the Shari'a, but most people are not able to understand it. Mukhtār 'Ațārid's view reflects the response of a scholar who inherits the tradition of Sunni Sufistic orthodoxy to the development of Sufism in the archipelago which has spanned from the 17th century until now.
\end{abstract}

Keywords: the dignity of seven, Sundanese, Sufism, Sunni 


\begin{abstract}
ABSTRAK
Kajian ini memfokuskan pada masalah wacana tasawuf Nusantara di Mekah pada awal abad ke-20. Objek utamanya adalah tanggapan Mukhtār 'Ațārid al-Bughūrī (1862-1930), ulama Sunda yang mengajar di Mekah, terhadap konsep martabat tujuh. Ia menuangkannya dalam dua kitab berbahasa Sunda yang dicetak di Mesir, Kifāyah al-Mubtadi'ìn dan Hidāyah al-Mubtadi'in. Melalui pendekatan sejarah sosial, hasil kajian menunjukkan bahwa tanggapan Mukhtār 'Ațārid mencerminkan kepentingan ortodoksi Sunni dalam bidang tasawuf yang bertumpu pada syariat. Pandangan tersebut cenderung menolak penyimpangan ajaran martabat tujuh di Nusantara yang dianggapnya heterodoks dan menyimpang. Sementara dalam kasus ajaran kesatuan eksistensi (tauhīd al-wujūd) Ibn 'Arabī, al-Jilī dan al-Burhānfūrī, Mukhtār 'Ațārid terlihat meluruskan kesalahpahaman orang terhadap ajarannya itu. Mukhtār 'Ațāid al-Bughūrī menganjurkan untuk berbaik sangka pada ajarannya, karena diyakini merupakan ahli hakikat yang benar dan sesuai dengan syariat, tetapi kebanyakan orang tidak mampu memahaminya. Pandangan Mukhtār 'Ațārid mencerminkan respons seorang ulama pewaris tradisi ortodoksi sufistik Sunni terhadap perkembangan tasawuf di Nusantara yang membentang sejak abad ke-17 hingga sekarang.
\end{abstract}

Kata kunci: martabat tujuh, bahasa Sunda, tasawuf, Sunni

\title{
PENDAHULUAN
}

Diskursus penolakan atas ajaran mistik filosofis di Nusantara sudah berlangsung sangat lama. Ajaran tasawuf tersebut dianggap heterodoks dan menyimpang dari ajaran syariat. Kasus pelarangan terhadap ajaran Ḥamzah Fanșūrī (diduga hidup antara 1527-1620-an) ${ }^{1}$ dan Shamsuddīn al-Sumatrā'̄ (w. 1630) yang dianggap panteistik oleh Nūr al-Dīn al-Rānīrī (w. 1658) pada abad ke-17 menjadi salah satu kontroversi paling awal dalam sejarah pemikiran sufistik Nusantara. ${ }^{2}$ Diskursus heterodoksi tasawuf Nusantara kemudian berlanjut saat Ibrāhīm alKurān̄̄ (1615-1690), ulama besar di Haramain abad ke-17,

${ }^{1}$ Verena Meyer, 'Translating Divinity: Punning and Paradox in Hamzah Fansuri's Poetic Sufism', Indonesia and the Malay World, 47.139 (2019), 357.

${ }^{2}$ Syed Muhammad Naguib Al-Attas, The Mysticism of Hamzah Fanșūrī (Kuala Lumpur: University of Malaya Press, 1970), 31-65. 
memberikan respons terhadap ajaran wahdatul wujūd yang berkembang di Nusantara. ${ }^{3}$ Al-Kurānī berusaha meluruskan pandangan tentang wahdatul wujüd dilihat dari sudut pandang ajaran ortodoksi Sunni.

Respons terhadap heterodoksi tasawuf di Nusantara ternyata tidak hanya berhenti pada al-Kurānī. Para sarjana belum banyak mengetahui bahwa jauh setelah respons al-Kurānī di Mekah pada abad ke-17, ulama Nusantara yang menjadi guru di Mekah pada awal abad ke-20 juga memberikan tanggapan serupa terhadap diskursus heterodoksi tasawuf di Nusantara. Mukhtār 'Ațārid al-Bughūrī (1862-1930) yang selama hampir 30 tahun (1903-1930) bermukim, belajar dan mengajar di Mekah memberi-kan responsnya terhadap ajaran martabat tujuh (marātib al-sab', martabat pitu) yang berkembang di Nusantara. Ia menuangkan tanggapan itu dalam beberapa karya yang berbahasa Sunda, yaitu Kifāyah al-Mubtadi'ìn (1341/1922) dan Hidāyah al-Mubtadi' ìn (1346/1927). ${ }^{4}$ Karya yang ditulis dengan aksara pegon itu dicetak di Mesir oleh penerbit Mustafá al-Bābī al-Halabī wa Awlāduh bi Miṣr. Meski karyanya ditulis sebagai pengantar, dasar pengajaran teologi dan tasawuf bagi para pelajar Sunda di Mekah, tetapi di dalamnya, Mukhtār 'Ațāid memberikan tanggapan serius terhadap beberapa ajaran tasawuf di Nusantara yang dianggap menyimpang dari ajaran syariat.

Kajian ini penting untuk membuktikan bahwa respons ulama Mekah terhadap diskursus heterodoksi sufistik di Nusantara tidak hanya terjadi pada abad ke-17, tetapi terus berlangsung sampai awal abad ke-20. Bahkan respons yang diberikan oleh ulama Mekah tidak lagi didominasi ulama Timur

${ }^{3}$ Oman Fathurahman, 'Ithaf Al-Dhaki by Ibrāhīm Al-Kurān̄i: A Commentary of Wahdat Al-Wujud for Jawi Audience', Archipel, 81 (2011), 177-98.

${ }^{4}$ Raden Al-Hājj Muhammad Mukhtār bin Raden Natanagara, Kifāyah Al-Mubtadi'̄̄n F̄̄ 'Ibādah Rabb Al-'Ālamīn (Kairo: Shirkah Maktabah wa Maṭba'ah Mustafá al-Bāb̄̄ al-Halab̄̄ wa Awlāduhu bi Miṣr, 1954); Raden Muhammad Mukhtār bin Raden Natanagara, Hidāyah Al-Mubtadi'īn Ilá Sulūk Maslak Al-Muttaqīn (Kairo: Mustafá al-Bābī al-Ḥalabī wa Awlāduh bi Miṣr, 1346). 
Tengah, tetapi juga melibatkan ulama Nusantara sendiri yang menjadi guru di Mekah. Ini menunjukkan bahwa ulama Nusantara diakui memiliki otoritas dalam memberikan fatwa keagamaan atas masalah yang dihadapi oleh Muslim Nusantara. ${ }^{5}$ Hal ini merupakan sebuah reputasi yang sulit ditemukan lagi pada masa sekarang di tengah semakin merosotnya citra Muslim Indonesia di Timur Tengah yang lebih dikenal sebagai salah satu negara pemasok buruh kasar terbesar. ${ }^{6}$ Pertanyaannya, bagaimana respons Mukhtār 'Ațārid terhadap ajaran martabat tujuh yang berkembang di Nusantara? Bagaimana tanggapannya terhadap ajaran Ibn 'Arabi, al-Burhānfürī dan al-Jilī? Mengapa ia cenderung menolak istilah martabat tujuh dan membenarkan ajaran tasawuf filosofis dari para sufi tersebut? Beberapa pertanyaan masalah tersebut akan dijawab dalam artikel ini.

Berdasarkan sejumlah kajian, belum banyak sarjana yang menyoroti posisi ulama Nusantara di Mekah dan tanggapan mereka terhadap berbagai isu keagamaan di Nusantara. Studi Azra dan Basri misalnya, cenderung menyoroti jaringan intelektual antara Haramain dan Nusantara yang berlangsung sejak abad ke-17 sampai 19. ${ }^{7}$ Begitu pun dengan kajian Fathurahman dan Knysh yang mengkaji al-Kurānī cenderung memfokuskan pada posisi dan tanggapan al-Kurān̄ terhadap masalah tasawuf di Nusantara abad ke-17. ${ }^{8}$ Sedangkan studi Kaptein tentang fatwa ulama Mekah abad ke-19, Aḥmad bin

5Jajang A Rohmana, 'Authorship of The Jāwī "Ulamā” in Egypt: A Contribution of Nawawī Banten and Haji Hasan Mustapa to Sharh Tradition', Epistemé: Jurnal Pengembangan Ilmu Keislaman, 15.2 (2020), 221-64.

${ }^{6}$ Sumanto Al-Qurtuby, Saudi Arabia and Indonesian Networks, Migration, Education, and Islam (London: I.B. Tauris, 2020), 114-5.

${ }^{7}$ Azyumardi Azra, The Origins of Islamic Reformism in Southeast Asia: Networks of Malay-Indonesian and Middle Eastern 'Ulama' in the Seventeenth and Eighteenth Centuries (Honolulu: ASAA-Allen \& Unwin and University of Hawai'i Press, 2004), 5; Basri, Indonesian 'Ulamā' in the Haramayn and the Transmission of Reformist Islam in Indonesia (18001900), Ph.D. Dissertation (University of Arkansas, 2008), 9.

${ }^{8}$ Alexander Knysh, 'Ibrāhīm Al-Kūrān̄̄ (d. 1101/1690), an Apologist for 'waḥdat Al-Wujūd"', Journal of the Royal Asiatic Society, 5.1 (1995); Oman Fathurahman, Ithaf Al-Dhaki, Tafsir Waḥdatul Wujūd Bagi Muslim Nusantara (Bandung: Mizan, 2012). 
Zain̄̄ Daḥlān (1817-1886) dan beberapa ulama lainnya dalam Muhimmàt al-Nafā'is, umumnya terkait dengan masalah hukum fikih yang diajukan kaum Muslim Nusantara. ${ }^{9}$ Beberapa sarjana yang mengkaji tentang Mukhtār 'Ațārid juga sama sekali belum menyentuh responsnya terhadap isu tasawuf Nusantara. Mereka cenderung memfokuskan pada masalah diskursus tentang hukum keharaman belut di Mekah dan posisi Mukhtār 'Ațāid dan karyanya dalam jaringan intelektual di Mekah dan Nusantara. ${ }^{10}$ Kajian ini berusaha menjelaskan tentang kontribusi penting ulama Nusantara di Mekah pada awal abad ke-20 yang menjadikan karyanya sebagai sumber belajar dan berdiskusi terkait masalah sosial-keagamaan di Nusantara. Kedua karya Mukhtār 'Ațārid mencerminkan gambaran bagai-mana posisinya dalam menghadapi masalah tasawuf Nusantara yang juga menjadi bahan perbincangan koloni Jawah di Mekah.

Tulisan ini lebih memfokuskan pada tanggapan Mukhtār 'Ațārid terhadap ajaran martabat tujuh di Nusantara. Penggunaan metode kajian kepustakaan dengan pendekatan sejarah sosialintelektual untuk menyingkap konteks historis penguatan ortodoksi tasawuf Sunni yang dilakukan Mukhtār 'Ațārid dibalik respons kerasnya terhadap ajaran martabat tujuh menjadi bagian tidak terpisahkan dari proses pengumpulan dan analisis data. Sejarah sosial-intelektual dimaksudkan sebagai kajian terhadap faktor-faktor sosial-intelektual yang mempengaruhi terjadinya peristiwa sejarah di mana teks berkontribusi terhadap penjelasan

${ }^{9}$ Nico Kaptein, Muhimmāt Al-Nafā'is: A Bilingual Meccan Fatwa Collection for Indonesian Muslims from the End of the Nineteenth Century (Jakarta: INIS, 1997), 9-14.

${ }^{10}$ Sunarwoto, 'Sheikh Mukhtār 'Ațārid on Belut', IJIPS, 6.1 (2012), 33-47; Ginanjar Sya'ban, 'Al-Syaikh Muhammad Mukhtār Bin 'Ațārid AlBughūrī Al-Jawi Thumma Al-Makki (1868-1930 M) Dan Jaringan Ulama Sunda Timur Tengah Awal Abad 20 M', International Journal of Pegon, 1.1 (2018), 39-62; Ahmad Ginanjar Sya'ban, 'Al-Shaikh Mukhtār Bin 'Ațārid AlBūghūrī Al-Jāwī Thumma Al-Makkī (1862-1930) Wa Al-Kutub AlȘundāwiyyah Al-Maṭbū'Ah F̄̄ Makkah Wa Al-Qāhirah Awā'il Al-Qarn Al'Ishrīn', Islam Nusantara, II.1 (2021), 93-112. 
sejarah. ${ }^{11}$ Di sini teks berbahasa Sunda karya Mukhtār 'Ațārid sebagai sumber data primer diyakini memiliki peran penting dalam memengaruhi penguatan ortodoksi tasawuf Sunni terhadap orang Sunda yang belajar di Mekah pada awal abad ke-20.

Sebagai seorang ulama yang hidup pada masa peralihan kekuasaan politik di Mekah pada awal abad ke-20, yakni dari Turki Usmani ke Dinasti Saudi yang berpaham Salafi/Wahabi, ${ }^{12}$ Mukhtār 'Ațārid tidak saja berusaha menegaskan posisinya sebagai penjaga tradisi ortodoksi tradisionalis Sunni, tetapi juga membersihkan elemen-elemen tasawuf di kalangan Muslim Nusantara yang dianggap tidak sesuai dengan syariat. Ia memiliki posisi penting dalam upaya membentuk dan memperbarui identitas mistisisme Islam di Nusantara yang selama ini dikesankan pinggiran, heterodoks, dan sinkretis. ${ }^{13}$

\section{HASIL DAN PEMBAHASAN}

\section{Martabat Tujuh dan Heterodoksi Tasawuf Nusantara}

Martabat tujuh secara filosofis awalnya digunakan untuk menjelaskan penciptaan makhluk oleh Tuhan. Ajaran ini meyakini bahwa keberadaan makhluk berasal dari Tuhan melalui manifestasi (tajallī) Tuhan atas diri-Nya. Eksistensi makhluk mewujud melalui proses tujuh tahapan, yaitu ahadiyyah, wahdah, wāhidiyyah, 'ālam arwāh, 'ālam mithāl, 'ālam ajsām, dan insān kāmil. Ketujuh martabat ini kemudian dijadikan dasar tahapan perjalanan spiritual yang berbalik (naik, taraqq $\vec{\imath}$ ) melakukan penyatuan eksistensial dengan Tuhan (wahdatul wujüd), berasal dari Tuhan lalu menyatu kembali dengan Tuhan secara eksistensial. $^{14}$

${ }^{11}$ Donald M. MacRaild dan Avram Taylor, Social Theory and Social History (New York: Palgrave MacMillan, 2004), 119.

${ }^{12}$ David Commins, The Wahhabi Mission and Saudi Arabia (London: I.B. Tauris, 2006), 72.

${ }^{13}$ Oman Fathurahman, "Sejarah Pengkafiran Dan Marginalisasi Paham Keagamaan Di Melayu Dan Jawa", Analisis, IX.2 (2011), 459.

${ }^{14}$ Jajang A Rohmana, "The Doctrin of Seven Grades in Hasan Mustapa's Verse', in Hasan Mustapa: Ethnicity and Islam in Indonesia, ed. by Julian Millie (Monash: Monash Publishing University, 2017), 120. 
Secara historis, mulanya ajaran martabat tujuh bersumber dari kitab Tuhfah al-Mursalah ilá Rūh al-Nabì karya AlBurhānfūrī (1545-1620), seorang ulama asal India. Ia berusaha menyederhanakan kompleksitas martabat wujud dalam ajaran tasawuf Ibn 'Arabī dan al-Jilī yang didudukkan dalam konteks tafsir rekonsiliatif sufistik Sunni. ${ }^{15}$ Ortodoksi tasawuf Sunni yang dibawa oleh al-Burhānfürī tergambar dalam komentarnya sendiri atas kitab Tuhfah dalam al-Haqīqah al-Muwāfaqah li alSharì'ah yang mencerminkan rekonsiliasi ajaran sufistik dengan syariat. ${ }^{16}$ Ajaran martabat tujuh kemudian berkembang di kalangan pengikut tarekat Shattariyah di India. ${ }^{17}$ Selain itu, hadirnya ajaran martabat tujuh dalam kitab Tuhfah juga tidak dapat dilepaskan dari situasi di India pada masanya yang didominasi kecenderungan berkembangnya heterodoksi Islam yang didekatkan dengan ajaran Hindu terutama pada masa Akbar (1573-1605) dan Jehangir (1605-1627). Ajaran heterodoks ini kemudian memicu reaksi 'Umar al-Shirhindī (1564-1624) untuk membela ortodoksi Sunni. $^{18}$

Perdebatan heterodoksi sufistik, seperti yang terjadi di India, juga berkembang di kalangan pengikut Shattariyah di Nusantara. Nūr al-Dīn al-Rānīrī (w. 1658) menjadi penggerak utama dalam membela ortodoksi tasawuf Sunni di Aceh. Ia menganggap ajar-an mistik filosofis yang dibawa pendahulunya, Hamzah Fanșūrī (diduga hidup antara 1527-1620-an) dan Shamsuddīn al-Sumatrā'̄̄ (diduga 1550-1630), telah

${ }^{15}$ Yunasril Ali, Manusia Citra Ilahi, Pengembangan Konsep Insan Kamil Ibn 'Arabī Oleh Al-Jili (Jakarta: Paramadina, 1997), 129.

${ }^{16}$ A.H. Johns, The Gift Adressed to the Spirit of the Prophet (Canberra: Center of Oriental Studies A.N.U, 1965), 5; Iin Suryaningsih, 'Al-Haqiqah Al-Muwafaqah Li Al-Shari'ah: Al-Tasaluh Bayn Al-Tasawwuf Wa AlShari'ah Bi Nusantara Fi Al-Qarn Al-Sadis 'Ashr Al-Miladi', Studia Islamika, 20.1 (2013), 97-127.

${ }^{17}$ J. Spencer Trimingham, The Sufi Orders in Islam (Oxford: Clarendon Press, 1977), 97-8.

${ }^{18}$ Oman Fathurahman, Tanbih Al-Masyi, Menyoal Wahdatul Wujūd Kasus Abdurrauf Singkel Di Aceh Abad 17 (Bandung: Mizan, 1999), 41. 
menyimpang dari syariat. ${ }^{19}$ Fatwa al-Rānīrī berakibat pada pembakaran berbagai karangan Hamzah Fanșūrī dan Shamsuddīn al-Sumatrā'̄ yang diikuti pula oleh penghukuman atas para pengikutnya. $^{20}$ Kasus ini kemudian mendapat tanggapan serius dari al-Kurānī (1616-1690) dan 'Abdurra'ūf bin 'Alī al-Jāwī alSinkilī (1615-1693). Keduanya merupakan murid Aḥmad alQushash̄̄ (1583-1660), ulama Shattariyah di Madinah. ${ }^{21}$ Sebagaimana gurunya, al-Kurān̄̄ berusaha meluruskan kesalahpahaman terhadap ajaran martabat tujuh dalam Tuhfah yang dianggap heterodoks, panteis dan mengesampingkan syariat. Ia memberikan respons atas masalah wahdatul wujūd yang diperbincangkan di Nusantara dalam kitab Ithậf al-Dhakī. ${ }^{22}$

Penyebaran ajaran martabat tujuh di kalangan pengikut tarekat Shattariyah di Nusantara semakin meningkat pesat di tangan 'Abdurra'ūf al-Sinkilī, khalifah utama Shat-tariyah di Aceh. Ia membangun jaringan Shattariyah melalui muridmuridnya yang tersebar di Sumatera, Jawa, Sulawesi, Buton hingga Malaysia. ${ }^{23}$ Di antara murid al-Sinkili yang terke-nal adalah Burhānuddīn (1646-1692) dari Ulakan Sumatera Barat dan 'Abdul Muhyī (1640-1715) dari Pamijahan Jawa Barat. 'Abdul Muhyī dianggap paling banyak berperan dalam penyebaran tarekat Shattariyah dan martabat tujuh di Jawa dan tatar Sunda dengan tanpa adanya pelucutan ajaran wah̆datul wujūd sebagaimana di Minangkabau. ${ }^{24}$

${ }^{19}$ Werner Kraus, 'The Shattariya Sufi Brotherhood in Aceh', in Aceh History, Politics and Culture, ed. by Arndt Graf Et.al (Singapore: Iseas, 2010), 212.

${ }^{20}$ Azra, The Origins, 53; A.H. Johns, 'Islam in Southeast Asia: Reflections and New Directions', Indonesia, 19 (1975), 45.

${ }^{21}$ Oman Fathurahman, Tarekat Syattariyah Di Minangkabau (Jakarta: Prenada Media, EFEO, PPIM, KITLV, 2008), 32.

${ }^{22}$ Fathurahman, Ithaf Al-Dhaki, 6; Fathurahman, 'Ithaf Al-Dhaki by Ibrāhīm Al-Kurānī, 177-98.

${ }^{23}$ Abdul Rahim Yunus, 'Nazariyat Martabat Tujuh Fi Nizam AlMamlakah Al-Butaniyyah', Studia Islamika, 2.1 (1995), 93-110.

${ }^{24}$ Fathurahman, Tarekat Syattariyah Di Minangkabau, 35, 91-98; Tommy Christomy, 'Shattariyah Tradition in West Java: The Case of Pamijahan', Studia Islamika, 8.2 (2001). 
Perkembangan martabat tujuh di tanah Jawa dan Sunda kemudian mengalami banyak modifikasi sehingga seringkali banyak disalahpahami. Dalam tradisi sastra Keraton Jawa abad ke-18 dan 19 misalnya, luasnya pengaruh martabat tujuh menjadi salah satu tema penting yang mengalami banyak harmonisasi. ${ }^{25}$ Berbagai elemen santri dalam ragam karya sastra Jawa menunjukkan adanya upaya rekonsiliasi dan harmonisasi antara mistisisme Jawa tradisional dan legalistik Islam ortodoks. Ricklefs menyebutnya sebagai bentuk sintesis mistik antara doktrin martabat tujuh dengan ajaran mistik Hindu-Jawa atau kejawen. Sebuah kesadaran identitas sebagai seorang Muslim sekaligus Jawa. ${ }^{26}$ Kecenderungan sintesis mistik ini misalnya, tampak pada Serat Centini, Serat Cebolek, Serat Dewa Ruci, Wirid Hidayat Jati, Suluk Wujil, Gatoloco dan banyak yang lainnya. ${ }^{27}$ Beberapa karya sastra Jawa itu bahkan terang-terangan memperlihatkan penentangannya terhadap ortodoksi syariat. ${ }^{28}$

Pengaruh martabat tujuh di Priangan akhir abad ke-19 menyebar dalam bentuk wawacan dan dangding, sebuah karangan puisi berbentuk pupuh, seperti terlihat dalam Wawacan Muslimin-Muslimat dan dangding Haji Hasan Mustapa (18521930). ${ }^{29}$ Bahkan beberapa penyimpangan pengamal tarekat dari syariat kemudian mendorong Sayyid 'Uthmān, mufti Batavia, melakukan banyak kritik. Sayyid 'Uthmān menyusun beberapa

${ }^{25}$ P.J. Zoetmulder, Manunggaling Kawula Gusti, Pantheisme Dan Monisme Dalam Sastra Suluk Jawa, terj. Dick Hartoko (Jakarta: Gramedia Pustaka Utama, 1991), 127, 368.

${ }^{26}$ M.C. Ricklefs, Mengislamkan Jawa, terj. FX. Dono Sunardi dan Satrio Wahono (Jakarta: Serambi, 2013), 36-7.

${ }^{27}$ S. Soebardi, 'Santri-Religious Elements as Reflected in the Book of Centini', Bijdragen Tot de Taal-, Land-En Volkenkunde, 127.3 (1971), 349.

${ }^{28}$ Karel Steenbrink, 'Opposition to Islamic Mysticism in NineteenthCentury Indonesia', in Islamic Mysticism Contested, Thirteen Centuries of Controversies and Polemics, ed. by Bernard Radtke, Frederick de Jong (Leiden-Boston: Brill, 1999), 694.

${ }^{29}$ Jajang A. Rohmana, 'Sundanese Sufi Literature and Local Islamic Identity: A Contribution of Haji Hasan Mustapa's Dangding', Al-Jami'ah: $\begin{array}{llll}\text { Journal of Islamic Studies, } 50.2 & \text { (2012), 303-27 }\end{array}$ <https://doi.org/10.14421/ajis.2012.502.303-327>. 
karangan yang berisi kritik terhadap kelompok tarekat dan diduga salah paham hingga terlibat polemik dengan Hasan Mustapa terkait apa yang disebutnya sebagai ilmu payakinan. ${ }^{30}$ Sebagaimana akan dijelaskan, kritik Sayyid 'Uthmān atas tarekat heterodoks itu menjadi contoh bagi Mukhtār 'Ațārid, karena ia sendiri berguru lama pada mufti Betawi itu sebelum ia berangkat ke Mekah pada 1903.

Mukhtār 'Ațārid yang hidup di awal abad ke-20 memiliki kesamaan pandangan dengan Sayyid 'Uthmān. Sebagaimana gurunya itu, ia terhubung dengan tradisi tarekat di Mekah. Mukhtār 'Ațārid diketahui bergabung dengan tarekat Naqshabandiyah dan mengamalkan zikirnya bersama murid-muridnya. Beberapa karyanya juga mengutip banyak sumber dari alGhazālī dan menyebut nama Junaid al-Baghdadi. Hal ini menjadi ciri penting upayanya untuk berusaha meluruskan paham tasawuf Nusantara ke arah rekonsiliasi dengan syariat. Seperti akan terlihat, ia berusaha meluruskan paham martabat tujuh yang berkembang di Nusantara dengan mengembalikan pada syariat. Ia kemudian memilih menggunakan istilah tauhīd al-wujūd sebagaimana dimaksudkan oleh para penggagasnya seperti Ibn 'Arab̄̄, al-Jilī dan al-Burhānfūrī.

\section{Mukhtār 'Ațārid dan Karyanya dalam Bidang Tasawuf}

Mukhtār 'Ațārid memiliki nama lengkap al-Syaikh Muḥammad Mukhtār ibn 'Ațārid al-Bughūrī al-Jāwī yang terkenal juga dengan gelar al-Batawī al-Makkī al-Shāfí' ${ }^{31}{ }^{31}$ Ia dikenal sebagai ulama ahl al-sunnah wa al-jamā'ah yang dikenal ahli bidang ilmu falak (astronomi), hadis, tasawuf dan fikih. ${ }^{32}$

${ }^{30}$ Nico J.G. Kaptein, Islam, Colonialism and the Modern Age in the Netherlands East Indies: A Biography of Sayyid 'Uthmān (1822-1914) (Leiden: Brill, 2014), 119, 193.

31، Abdullāh bin 'Abdurraḥmān bin 'Abdurrahīm Al-Mu'allimī, A'lām Al-Makkiyyīn Min Al-Qarn Al-Tāsi' Ilá Al-Qarn Al-Rābi' 'Ashar Al-Hijrī (Mekah: Mu'assasah al-Furqān li al-Turāth al-Islāmī, 2000), 273.

${ }^{32}$ Riḍā' bin Muḥammad Șāfĩ al-Dīn Al-Sanūsī, Dawr 'Ulamā' Makkah Al-Mukarramah Fì Khidmah Al-Sunnah Wa Al-Sīrah Al-Nabawiyyah 
Kepakarannya itu didasarkan pada beberapa karya-karyanya yang mendapat tempat di kalangan kaum Muslim dan masih terus dicetak hingga sekarang. Mukhtār 'Ațārid lahir dari keluarga menak Sunda (priayi). Hal ini terlihat dari nama ayahnya, Raden Natanagara, yang dalam beberapa karyanya sering juga disebut dengan nama 'Ațārid. ${ }^{33}$ Raden Natanagara merupakan anak Raden Adipati Wiratanudatar VI, Bupati Cianjur (sekitar 1776-1813) yang dikenal dengan nama Dalem Enoch. ${ }^{34}$

Mukhtār 'Ațārid lahir di Bogor, Jawa Barat pada 14 Sya'ban 1278/13 Februari 1862. Ia belajar ilmu-ilmu dasar keislaman dari ayahnya, lalu belajar pada Sayyid 'Uthmān (1822-1913), mufti Batavia pada tahun 1882. Sayyid 'Uthmān dikenal sebagai keturunan Arab Hadrami yang bekerja sebagai penasehat Belanda untuk urusan Arab dan menulis sejumlah karya polemis berbahasa Arab dan Melayu terkait masalah tarekat dan fikih. Banyak karyanya yang kemudian diterjemahkan pula ke dalam bahasa Sunda, salah satunya oleh Raden Haji Azhari Bandung. ${ }^{35}$ Pergaulannya dengan Sayyid 'Uthmān di Batavia (Jakarta) boleh jadi kemudian berpengaruh terhadap Mukhtār 'Ațārid. Ia kelak tidak hanya menulis karya polemis di Mekah seperti al-Sawā'iq al-Muhriqah yang membantah hukum keharaman belut, tetapi juga memberikan tanggapan terhadap penyimpangan ajaran martabat tujuh di Nusantara sebagaimana akan dijelaskan.

Setelah belajar pada Sayyid 'Uthmān, Mukhtār 'Ațārid kemudian pergi berhaji dan menetap di Mekah sejak 1903 hingga

(Madinah: Majma' al-Mulk Fahd li Ṭabā'ah al-Muṣhaf al-Sharīf bi alMadīnah al-Munawwarah, t.th.), 56.

${ }^{33}$ Raden Al-Hājj Muhammad Mukhtār bin Raden Natanagara, Kifāyah al-Mubtadi'īn, 1 .

${ }^{34}$ Nina H. Lubis, Kehidupan Kaum Menak Priangan 1800-1942 (Bandung: Pusat Informasi Kebudayaan Sunda, 1998), 152.

${ }^{35}$ Nico J.G. Kaptein, Islam, Colonialism, 219. Belum banyak informasi tentang sosok Raden Azhari ini. 
meninggal dunia tahun $1930 .^{36}$ Selama hampir 30 tahun, ia menjalani hari-harinya dalam aktivitas pembelajaran di Mekah. Di sini ia belajar keilmuan Islam pada banyak ulama Mekah dan Madinah. ${ }^{37}$ Selain itu, ia juga belajar pada beberapa ulama Nusantara lainnya yang menjadi guru di Mekah.

Mukhtār 'Ațārid kemudian mengajar di salah satu halaqah (lingkaran pengajaran) di Masjidil Haram tepatnya di Haswah Bāb al-Nabi ${ }^{38}$ Majelisnya dihadiri sekitar 400 murid terdiri dari para ulama dan murid senior yang diadakan setelah salat isya. Setelah salat subuh, ia juga mengajar ilmu alat (nahwwu-șaraf) dan balāghah, lalu setelah salat asar mengajar kitab Ihyya' 'Ulüm a-Dìn karya Abū Hāmid al-Ghazālī (1058-1111), ulama Sunni terkenal, dan setiap hari Selasa mengajar ilmu falak atau astronomi. $^{39}$ Sebuah laporan tahun 1910 menyatakan bahwa Mukhtār 'Ațārid termasuk salah satu dari delapan ulama asal Nusantara $(a l-J \bar{a} w \bar{\imath})$ yang mengajar di Masjidil Haram dan mendapatkan bayaran dari syarif Mekah, sesuatu yang tidak didapatkan sebelumnya. Ia termasuk salah satu tokoh kunci yang memimpin komunitas Jāwah (Nusantara) di antara ratusan guru asal Nusantara di Mekah. ${ }^{40}$

Selain mengajar di Ḥaram, Mukhtār 'Ațārid juga menjadikan rumahnya sebagai tempat belajar bahasa Arab, tasawuf dan ilmu falak setiap pagi dan sore hari. Sebagai pengikut tarekat Qadiriyah dan Naqshabandiyah, pada malam Jumat, ia sering

${ }^{36}$ Yūsuf 'Abdurraḥmān Al-Mar'ashl̄̄, Mu'jam Al-Ma'ājim Wa AlMashīkhāt Wa Al-Fahāris Wa Al-Barāmij Wa Al-Athbāt, Vol. II (Riyad: Maktabah al-Rushd, 2002), 395.

${ }^{37}$ Muhammad Mukhtār al-Dīn bin Zain al-'Ābidīn Al-Falimbān̄̄, Bulūgh Al-Amān̄̄ F̄̄ Al-Ta'rīf Bi Shuyūkh Wa Asānīd Musnid Al-'Așr AlShaikh Muḥammad Yāsīn Bin Muhammad 'İsá Al-Fadan̄̄ Al-Makkī (Beirut: Dār Qutaibah, 1988), 40.

${ }^{38}$ Husain bin Muhammad Hasan Shu'aib, Al-Dawr Al-Tarbawī Li Halaqāt Al-'Ilm Bi Al-Masjid Al-Harām F̄̄ 'Abd Al-Mālik 'Abd Al-Azīz, Kulliyyah Al-Tarbiyyah Bi Makkah Al-Mukarramah (Mekah: Jāmi’ah Umm al-Qurá, 1428), 134, 353, 362.

39،Abd al-Lațîf bin 'Abdullāh bin Dahīs, Al-Hayāh Al-'Ilmiyyah Fī Makkah, 387, 410.

${ }^{40}$ Michael Laffan, Islamic Nationhood and Colonial Indonesia, The Umma below the Winds (London: Routledge Curzon, 2003), 175. 
mengadakan majelis untuk berzikir yang dihadiri banyak orang yang dilanjutkan dengan jamuan makanan. Rumahnya berada di distrik al-Qushashiyyah di kaki bukit Jabal Abī Qubaish, Mekah. ${ }^{41}$ Ia dikenal zuhud, banyak beribadah, membaca salawat, berinfak pada para murid dan memotivasi mereka. ${ }^{42}$ Muridmuridnya tidak hanya dari Arab, Afrika dan Asia Selatan, tetapi banyak juga dari Nusantara. ${ }^{43}$ Ia meninggal pada 17 Rajab 1349 dan dimakamkan di Ma'lāh dekat makam Ibn Hajar al-Haitamī. ${ }^{4}$

Terdapat cukup banyak karya Mukhtār 'Ațārid yang berkaitan dengan ragam keilmuan Islam, baik hadis, fikih, doa dan wirid, peta kiblat, ilmu falak, teologi dan tasawuf. Ia menulisnya dalam bahasa Arab, Melayu dan Sunda. Tetapi, kiranya hanya dua karyanya di bidang tasawuf yang ditulis dalam bahasa Sunda, yaitu Kifāyah al-Mubtadi'̄̄n (1341/1922) dan Hidāyah alMubtadi'̄n (1346/1927). Kedua karangan ini dicetak di Mesir oleh penerbit Mustafá al-Bābī al-Halabī wa Awlāduh. Belakangan kitab Kifāyah al-Mubtadi'̄̄n juga diterbitkan oleh penerbit Bandung, Shirkah al-Ma'ārif li al-Ṭab' wa al-Nashr.

Kitab Kifāyah al-Mubtadi'in sebetulnya tidak hanya menjelaskan masalah tasawuf, tetapi juga teologi (uṣūl al-dīn) dan fikih. Mukhtār 'Ațārid menjelaskan bahwa ia membuat karangan bagi para murid tingkat dasar tersebut dengan cara menerjemahkan dari berbagai kitab, di antaranya karya-karya alGhazālī (1058-1111), seperti Bidāyah al-Hidāyah, al-Arba'īn fì

${ }^{41}$ Muhammad Mukhtār al-Dīn bin Zain al-'Ābidīn al-Falimbān̄̄, Bulūgh al-Amānī, 39.

${ }^{42}$ Maḥmūd Sa'̄̄ò bin Muhammad Mamdūḥ Al-Shāfi'̄̄, Tashnīf AlAsmā' Bi Shuyūkh Al-Ijāzah Wa Al-Simā', Vol. II (Beirut: Dār al-Kutub alMișriyyah, 1434), 569; Yūsuf Al-Mar'ashlī, Nathr Al-Jawāhir Wa Al-Durar F̄̄ 'Ulamā' Al-Qarn Al-Rābi' 'Ashar (Beirut: Dār al-Ma'rifah, 2006) 1476.

43، Abdullāh bin 'Abdurraḥmān bin 'Abdurrahīm al-Mu'allimī, A'lām al-Makkiyyīn, 561; 'Umar 'Abd Al-Jabbār, Siyar Wa Tarājim Ba'd 'Ulamā'Inā Fì Al-Qarn Al-Rābi' 'Ashr Li Al-Hijrah (Jeddah: Ṭuhāmah, 1982), 245.

${ }^{44}$ Edwin Wieringa, 'Mecca Has Spoken, Case Closed: Muhammad Hasan B. Kasim's 1913 Meccan Poem of Advice on Sarekat Islam', in Contuinity and Change In The Realms Of Islam, ed. by J. Van Steenbergen K.D Hulster (Leuven: Peeters, 2008), 637. 
Ușūl al-Dìn, dan Minhāj al- 'Ābidīn. Ia juga menggunakan karya Ibn Hajar al-Haitamī (1503-1566), ulama fikih terkenal, alZawājir 'an Iqtirāf al-Kabā'ir. Kitab Kifāyah al-Mubtadi'īn yang memuat masalah tasawuf, teologi dan fikih kiranya sangat dipengaruhi oleh sistematika pembahasan kitab Bidāyah alHidāyah dan al-Arba'īn fì Ușūl al-Dīn karya al-Ghazālì tersebut yang juga memuat pembahasan tiga bidang tersebut. ${ }^{45}$

Pengaruh karya-karya al-Ghazālī tersebut misalnya, terlihat dalam pembahasan tasawuf. Mukhtār 'Ațārid terlihat meringkas penjelasan beberapa fasal (bagian) pembahasan tentang syariat, tarekat dan hakikat, definisi tasawuf, rukun tarekat ahli tasawuf, muamalah atau hubungan sosial ahli tarekat, obat untuk penyakit hati, penjelasan tentang takwa, berbagai larangan (cegahan) untuk mata, telinga, lidah, perut, kemaluan, dua tangan dan dua kaki, serta 19 larangan untuk hati agar tidak melakukan maksiat batin. ${ }^{46}$ Kitab ini ditutup dengan penjelasan tentang bab etika (adab), terdiri dari adab pada Allah, adab bagi orang yang sedang belajar mengaji, adab anak pada kedua orang tua, adab istri pada suami, adab bagi orang yang punya istri, adab pada orang awam yang belum dikenal, syarat orang yang dapat dijadikan sahabat dan adab pada orang yang sudah kenal. ${ }^{47}$

Pembahasan tentang teologi (ușūl al-dīn) dalam kitab Kifāyah al-Mubtadi'̄on hampir sama penjelasannya dengan kitab karya Mukhtār 'Ațārid yang lain, seperti Ieu Kitāb 'Aqā'id Ahl al-Sunnah wa al-Jamā'ah. ${ }^{48}$ Kitab ini merupakan bahan ajar teologi yang meneguhkan sikapnya sebagai penganut ahl alsunnah wa al-jamāa'ah yang merujuk pada yang menganut

${ }^{45}$ Al-Imām Abī Hāāmid Muḥammad bin Muḥammad bin Muḥammad Al-Ghazālī, Bidāyah Al-Hidāyah (Beirut: Dār al-Minhāj, 2004); al-Imām

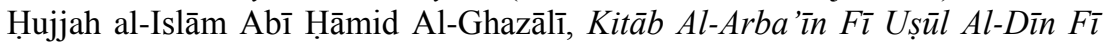
Al-'Aqā'Id Wa Asrār Al-'Ibādāt Wa Al-Akhlāq (Damaskus: Dār al-Qalam, 2003).

${ }^{46}$ Raden Al-Hāajj Muhammad Mukhtār bin Raden Natanagara, Kifāyah al-Mubtadi'īn, 83-110.

${ }^{47}$ Raden Al-Ḥājj Muhammad Mukhtār bin Raden Natanagara, Kifāyah al-Mubtadi'īn, 110-24.

${ }^{48}$ Raden al-Hāijj Muḥammad Mukhtār bin Raden Natanagara, Ieu Kitāb 'Aqā'Id Ahl Al-Sunnah Wa Al-Jamā'ah (Mesir: Mustafá al-Bābī al-Halabī wa Awlāduh bi Misr, 1341). 
teologi Asy'ariyah dan Maturidiyah, menerima fikih empat mazhab dan menganut rekonsiliasi tasawuf dan syariat sebagaimana al-Ghazālī dan Abū al-Qāsim Junaid al-Baghdādī (w. 910). Kitab Kifāyah al-Mubtadi'īn berisi penjelasan tentang makrifat kepada Allah, rasul, rukun iman, rukun Islam, dan berbagai macam bidah yang baik dan tercela dalam Islam. ${ }^{49}$ Sedangkan dalam pembahasan tentang fikih, ia menjelaskan tentang bab-bab fikih yang umumnya didapatkan dalam kitab-kitab fikih lainnya, dari bab țahārah (bersuci) sampai haji dan umrah. Mukhtār 'Ațārid memberikan penjelasan secara singkat dan padat mengingat pembaca kitab ini adalah para murid asal Jawa Barat yang baru belajar agama. ${ }^{50}$

Kitab karya Mukhtār 'Ațārid lainnya yang menjelaskan tentang tasawuf adalah Hidāyah al-Mubtadi'in. Kitab ini menjelaskan tentang tasawuf yang penjelasannya dibagi ke dalam sejumlah fasal. Secara berturut-turut dijelaskan tentang upaya menjaga tujuh anggota tubuh dari maksiat, yaitu mata, telinga, lidah, perut, kemaluan, dua tangan dan dua kaki; sepuluh perkara untuk membersihkan hati agar jauh dari maksiat batin yang diringkas dari kitab al-Arba'īn fì Ușūl al-Dīn karya alGhazālī, yaitu menjaga makanan, ucapan, marah, hasud, kikir, cinta nafsu, cinta dunia, takabur, ujub dan riya; ${ }^{51}$ sepuluh perkara tentang taat batin berupa ibadah dalam hati juga diringkas dari karya al-Ghazālī tersebut, yaitu khauf (takut), zuhud, sabar, syukur, ikhlas, tawakal, cinta (mahabbah), rida dan ingat mati. ${ }^{52}$ Bagian penutup dalam kitab ini menjelaskan tentang macammacam etika (adab) yang isinya hampir sama dengan kitab Kifāyah al-Mubtadi'ìn, yaitu adab bersahabat, adab orang alim,

\footnotetext{
${ }^{49}$ Raden al-Hājj Muhammad Mukhtār bin Raden Natanagara, Ieu Kitāb 'Aqā'Id, 10-11.

${ }^{50}$ Raden Al-Hājj Muhammad Mukhtār bin Raden Natanagara, Kifāyah al-Mubtadi'in, 35-83.

${ }^{51}$ Raden Muhammad Mukhtār bin Raden Natanagara, Hidāyah alMubtadi'in, 8-22.

${ }^{52}$ Raden Muhammad Mukhtār bin Raden Natanagara, Hidāyah alMubtadi'in, 22-39; al-Imām Ḥujjah al-Islām Abī Ḥāmid Al-Ghazālī, Kitāb alArba'ìn, 301-2.
} 
adab orang yang sedang belajar mengaji, adab anak kepada kedua orang tua, adab ayah mengajar anaknya, adab istri pada suami, adab suami pada istri, adab berhubungan intim (jimak), adab bergaul, syarat untuk memilih sahabat, adab pada sahabat, dan adab pada orang yang sudah kenal. ${ }^{53}$

Penjelasan di atas menunjukkan bahwa Mukhtār 'Ațārid merupakan ulama Nusantara yang menjadi salah satu penjaga tradisi ortodoksi tasawuf Sunni di Mekah. Karyanya yang banyak dipengaruhi oleh al-Ghazālī menunjukkan posisinya sebagai ulama ortodoksi Sunni. Karenanya, kuatnya ideologi tasawuf Sunni tergambar dalam kritik Mukhtār 'Ațārid terhadap penyimpangan ajaran martabat tujuh yang akan menjadi bahasan berikutnya.

\section{Kritik terhadap Martabat Tujuh, Ilmu Belewuk atau Ilmu Payakinan}

Terdapat banyak literatur yang memodifikasi ajaran martabat tujuh di Nusantara, seperti telah dijelaskan di atas. Di Melayu, Jawa, Sunda hingga Buton beredar literatur puisi dan prosa bahkan undang-undang yang menunjukkan pengaruh martabat tujuh. ${ }^{54}$ Berbagai modifikasi ajaran martabat tujuh ini kemudian semakin berkembang hingga memunculkan kesalahpahaman pandangan bahwa ajaran martabat tujuh dan wahdatul wujūd termasuk ajaran heterodoks dan menyimpang dari ajaran syariat. Hal ini terlihat dari begitu banyaknya cerita yang berkembang terkait penghukuman terhadap para penganut ajaran tersebut.

Cerita Syekh Siti Jenar yang dihukum mati karena ajaran Manunggaling Kawula Gusti berkembang sejak abad ke-16, boleh jadi merupakan cerita versi Jawa dari kasus al-Hallāj di Timur Tengah. Hal yang sama juga terjadi pada Syekh Among Raga, Ki Bebeluk dan Pangeran Panggung. Di Aceh abad ke-17, juga terjadi pembakaran buku dan pembunuhan terhadap

${ }^{53}$ Raden Muhammad Mukhtār bin Raden Natanagara, Hidāyah alMubtadi'in, 39-58.

${ }^{54}$ Jajang A Rohmana, 'The Doctrin of Seven Grades in Hasan Mustapa's Verse', 117-40. 
pengikut Hamzah Fanșūrī dan Shamsuddīn al-Sumatrā'̄̄. Selain itu, terdapat juga cerita versi Banjar di mana Haji Abdul Hamid juga dihukum mati karena menganut paham yang sama. ${ }^{55}$ Terdapat juga banyak kritik terhadap tarekat, seperti dilakukan Aḥmad Khațīb al-Minangkabāwī (1860-1912) terkait sifat kadim Allah, silsilah tarekat, dan praktik suluk. ${ }^{56}$ Belakangan terdapat juga polemik wah̆datul wujūd berupa surat kaleng yang dikirimkan terhadap Penghulu Bandung, Hasan Mustapa tahun 19021903. ${ }^{57}$ Sebagian sarjana menduganya sebagai kiriman Sayyid 'Uthmān, mufti Batavia. Ia kemudian menyusun beberapa karya yang mengkritik ajaran dan praktik tarekat yang dianggapnya menyimpang dari ajaran syariat. ${ }^{58}$

Mukhtār 'Ațārid, sebagaimana gurunya, Sayyid 'Uthmān, kiranya juga memberikan respons keras terhadap penyimpangan ajaran martabat tujuh dalam konteks cerita-cerita yang ia dengar sejak masih berada di Bogor dan Batavia. Ia menyebut ajaran itu dengan istilah ilmu belewuk (kotor) atau ilmu payakinan (peyakinan) atau ilmu alus (bagus). Ia memasukkan ajaran tersebut kepada ajaran bidah tercela (bid'ah madhmümah), karena menyalahi Al-Qur'an, hadis, ijmak dan kiyas. Mukhtār 'Ațārid misalnya, menegaskannya dalam kitab Kifāyah al-Mubtadi'̄n dan Hidāyah al-Mubtadi'in:

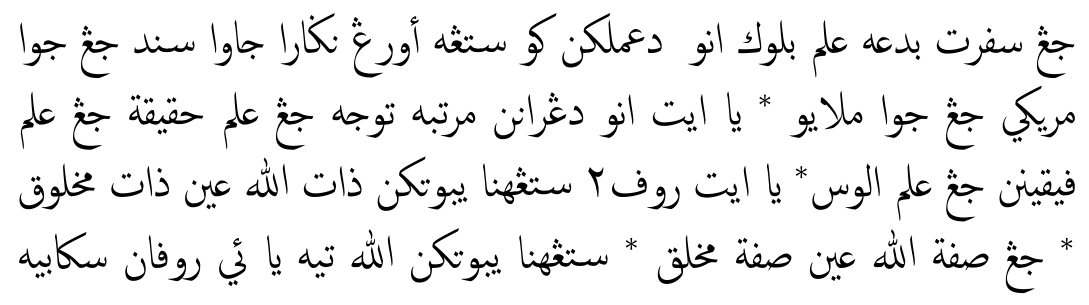

${ }^{55}$ Karel Steenbrink, Beberapa Aspek Tentang Islam Di Indonesia Abad Ke-19 (Jakarta: Bulan Bintang, 1984), 95-96, 198.

${ }^{56}$ Steenbrink, Beberapa Aspek Tentang Islam Di Indonesia Abad Ke19, 144 .

${ }^{57}$ Jajang A Rohmana, Membekap Halilintar: Polemik Wahdatul Wujud Dalam Naskah Injāz al-Wa'd fì Itfä' al-Ra'd Karya Haji Hasan Mustapa

(Garut: Layung, 2021), 4-5.

${ }^{58}$ Nico J.G. Kaptein, Islam, Colonialism, 119, 193. 


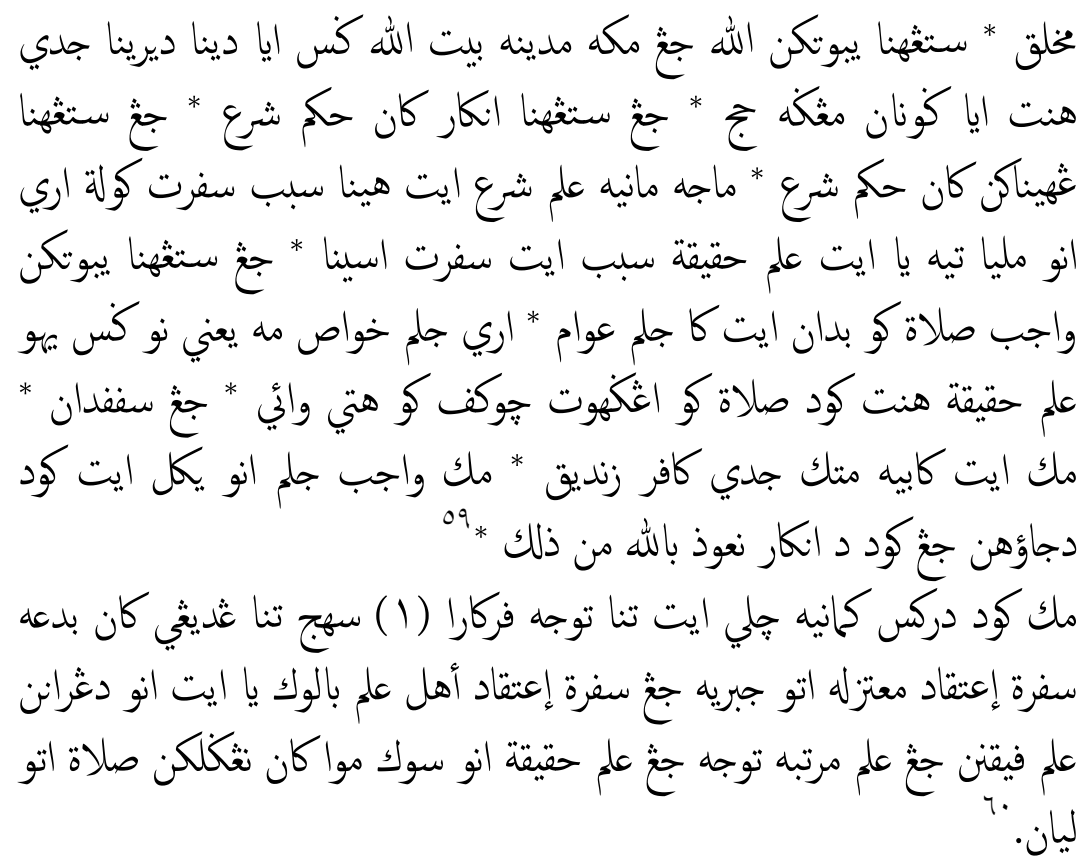

Jeung saperti bid'ah elmu Belewuk anu diamalkeun ku satengah urang nagara Jawa Sunda jeung Jawa Mriki jeung Jawa Malayu. Nyaeta anu dingaranan Martabat Tujuh jeung elmu hakekat jeung elmu payakinan jeung elmu alus. Nyaeta rupa-rupa satengahna nyebutkeun zat Allah 'aen zat mahluk. Jeung sipat Allah 'aen sipat mahluk. Satengahna nyebutkeun Allah the nyaeta rupana sakabeh mahluk. Satengahna nyebutkeun Allah jeung Mekah Madinah Baetullah geus aya dina dirina jadi henteu aya gunana munggah haji. Jeung satengahna ingkar kana hukum syara'. Jeung satengahna ngahinakeun kana hukum syara'. Majah maneh elmu syara' eta hina sabab saperti kulit ari anu mulya the nyaeta elmu hakekat sabab eta saperti eusina. Jeung satengahna nyebutkeun wajib salat ku badan eta ka jalma awam. Ari jalma khawas mah ya'ni nu geus nyaho elmu hakekat henteu kudu salat ku anggahota cukup ku hate wae. Jeung sapapadana. Maka eta kabeh matak jadi kapir zindik.

${ }^{59}$ Raden Al-Hājj Muhammad Mukhtār bin Raden Natanagara, Kifāyah al-Mubtadi'in, 32-33.

60 Raden Muhammad Mukhtār bin Raden Natanagara, Hidāyah alMubtadi'in, 4. 
Maka wajib jalma anu nyekel eta kudu dijauhan jeung kudu di ingkar na'udubillah min zalik.

Maka kudu diriksa ku maneh ceuli eta tina tujuh perkara (1) sahiji tina ngadenge kana bid'ah saperti itikad Muktazilah atawa Jabariyah jeung saperti itikad ahli elmu Belewuk nyaeta anu dingaranan elmu payakinan jeung elmu Martabat Tujuh jeung elmu hakekat anu sok mawa kana ninggalkeun salat atawa liyanna.

Terjemahan:

Dan seperti bidah ilmu belewuk (kotor) yang diamalkan oleh sebagian orang negeri Jawa Sunda dan Jawa Mriki dan Jawa Melayu. Yaitu, yang disebut martabat tujuh dan ilmu hakikat dan ilmu peyakinan dan ilmu alus (bagus). Yaitu, rupa-rupa sebagiannya menyebutkan Dzat Allah itu 'ain (esensi) dzat makhluk. Dan sifat Allah itu 'ain (esensi) sifat makhluk. Sebagiannya menyebutkan bahwa Allah itu inilah rupanya semua makhluk. Sebagiannya menyebutkan bahwa Allah dan Mekah, Madinah, Baitullah sudah ada dalam dirinya. Jadi, tidak ada gunanya pergi haji. Dan sebagian mengingkari hukum syariat. Dan sebagiannya menghinakan hukum syariat. Katanya, ilmu syariat itu hina sebab seperti kulit ari, yang mulya itu adalah ilmu hakikat, sebab itu seperti isinya. Dan sebagiannya menyebutkan wajib salat dengan badan itu bagi orang awam. Bahwa orang khawāṣ (khusus) itu yakni yang sudah mengetahui ilmu hakikat tidak harus salat dengan anggota badan, cukup dengan hati saja. Dan semisalnya. Maka, itu semua membuat jadi kafir zindik. Maka, wajib orang yang berpegang pada keyakinan itu harus dijauhi dan harus diingkari, kita berlindung kepada Allah dari hal itu...

Maka harus dijaga olehmu telinga dari tujuh perkara (1) kesatu, dari mendengarkan bidah seperti keyakinan Muktazilah atau Jabariyah dan seperti keyakinan ahli ilmu belewuk, yaitu yang disebut ilmu peyakinan dan ilmu martabat tujuh dan ilmu hakikat yang suka membawa pada meninggalkan salat atau lainnya...

Kutipan di atas menunjukkan bahwa dalam pemahaman Mukhtār 'Ațārid, martabat tujuh atau disebut juga dengan ilmu belewuk, ilmu payakinan atau ilmu alus tersebut termasuk pada ajaran bidah tercela, karena bertentangan dengan sumber pokok ajaran Islam. Menurutnya, ajaran itu sesat dan menyimpang dari ajaran Islam yang benar, karena menyamakan dzat, sifat dan rupa 
Allah dengan makhluk-Nya. Selain itu, ajaran tersebut juga dianggap mengingkari dan menghinakan syariat, seperti ibadah haji dan salat, sehingga dapat menjerumuskan pengikutnya menjadi kafir zindik. Pandangan ini menunjukkan bahwa Mukhtār 'Ațārid cenderung menilai negatif istilah martabat tujuh yang disamakannya dengan istilah ilmu belewuk, ilmu payakinan atau ilmu alus tersebut. Kiranya yang dimaksudkannya adalah penyimpangan ajaran itu yang dipahaminya sebagai ajaran yang cenderung panteis dan menolak syariat.

Kritik Mukhtār 'Ațāid terhadap panteisme dalam ajaran tasawuf heterodoks juga terlihat dalam karya lainnya, yaitu Ieu Kitab I'tiqād Ahl al-Sunnah wa al-Jamā'ah. Ia menegaskan tentang sifat Allah yang berbeda dengan makhluk (mukhālafah li al-hawädith). Menurutnya, karena sifat inilah maka Allah tidak menjadi satu dengan makhluk, tidak berdiam diri dalam diri makhluk, tidak di luar makhluk, dan makhluk juga tidak berdiam diri dalam dzat Allah. Mukhtār 'Ațārid menyatakan:

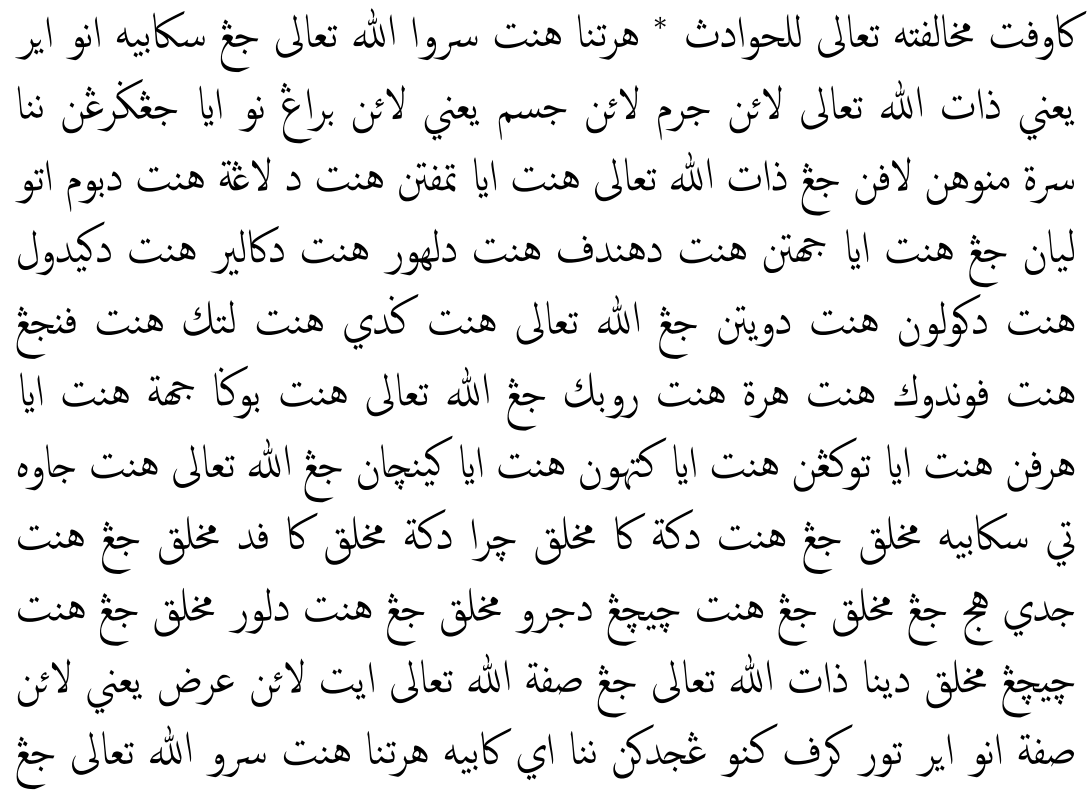


DISKURSUS TASAWUF NUSANTARA DI MEKAH: RESPONS MUKHTĀR 'AṬ̂̄RID AL-BUGHŪRİ TERHADAP

AJARAN MARTABAT TUJUH-Jajang A Rohmana

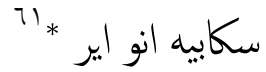

Kaopat, Mukhalafatuh Ta'ala li al-Hawadith. Hartina henteu sarua Allah Ta'ala jeung sakabeh anu anyar, yakni zat Allah Ta'ala lain jirim lain jisim, yakni lain barang nu aya junggiringanana sarta minuhan lapang. Jeung zat Allah Ta'ala henteu aya tempatna henteu di langit henteu di bumi atawa liyanna. Jeung henteu aya jihatna henteu di handap henteu di luhur henteu di kaler henteu di kulon henteu di wetan jeung Allah Ta'ala henteu gede henteu leutik henteu panjang henteu pondok henteu heureut henteu rubak jeung Allah Ta'ala henteu boga jihat henteu aya hareupna henteu aya tukangna henteu aya katuhuna henteu aya kencana jeung Allah Ta'ala henteu jauh ti sakabeh mahluk jeung henteu deukeut ka mahluk cara deukeut mahluk ka pada mahluk jeung henteu jadi hiji jeung mahluk jeung henteu cicing di jero mahluk jeung henteu di luar mahluk jeung henteu cicing mahluk dina zat Allah Ta'ala jeung sipat Allah Ta'ala eta lain 'arad yakni lain sipat anu anyar tur karep kanu ngajadikeunana. Ieu kabeh hartina henteu sarua Allah Ta'ala jeung sakabeh anu anyar.

Terjemahan:

Keempat (sifat yang wajib bagi Allah itu), mukhālafatuh ta'ālá li alhawādith (berbeda-Nya Allah Ta'ala dengan (makhluk-Nya) yang baru. Artinya, tidak sama Allah Ta'ala dengan semua yang baru, yakni dzat Allah Ta'ala bukan sosok, bukan jasad, yakni bukan barang yang ada tongkrongannya serta memenuhi lapin (sic!) (lapangan. Dan Allah Ta'ala tidak ada tempatnya, tidak di langit, tidak di bumi atau lainnya. Dan tidak ada arahnya, tidak di bawah, tidak di atas, tidak di utara, tidak di selatan, tidak di timur, tidak di barat. Dan Allah Ta'ala tidak besar, tidak kecil, tidak panjang, tidak pendek, tidak sempit, tidak luas. Dan Allah Ta'ala tidak memiliki arah, tidak ada depannya, tidak ada belakangnya, tidak ada kanannya, tidak ada kirinya. Dan Allah Ta'ala tidak jauh dari semua makhluk, dan tidak dekat pada makhluk seperti dekatnya makhluk pada makhluk, dan tidak jadi satu dengan makhluk, dan tidak berdiam diri dalam diri makhluk, dan tidak di luar makhluk, dan makhluk tidak berdiam diri dalam dzat Allah Ta'ala, dan sifat Allah

${ }^{61}$ Raden al-Hāijj Muḥammad Mukhtār bin Raden Natanagara, Ieu Kitāo 'Aqā'id Ahl al-Sunnah wa al-Jamā'ah, 3. 
Ta'ala itu bukan 'arad (aksiden), yaitu bukan sifat yang baru dan memiliki keinginan ada yang dijadikannya ini semua, artinya tidak sama Allah Ta'ala dengan semua yang baru.

Pernyataan tersebut menunjukkan bahwa Mukhtār 'Ațārid menolak doktrin panteistik yang mengakui adanya imanensi Tuhan dalam diri makhluk. Baginya, Tuhan tidak menjadi satu dengan makhluk. Ia menolak adanya pengetahuan tentang penyatuan eksistensial Tuhan dan hamba, sebagaimana dikenal dalam doktrin wahdatul wujūd. Ia menolak bahwa Allah dapat berdiam diri (menyatu) dalam diri hamba. Namun, bukan hanya penyatuan Tuhan dan hamba, Mukhtār 'Ațārid juga menolak doktrin transendensi Tuhan di luar makhluk. Penolakan penggambaran Tuhan dari sisi imanensi dan transendensi tersebut didasarkan pada keyakinan ajaran teologi Asy'ariyah bahwa Tuhan ada (wujud), tetapi bukan substansi atau benda (fisik) dan tidak dalam ruang apapun. Dia memiliki tangan, wajah dan lainnya sebagaimana digambarkan dalam Al-Qur'an, tetapi kaum Muslim harus mengimani saja tanpa perlu mempertanyakan "bagaimana" (bi la kaifa), karena penggambaran akal atas Tuhan akan mengarah pada penyerupaan-Nya dengan makhluk. ${ }^{62}$ Mukhtār 'Ațārid terlihat menggunakan teologi Asy'ariyah dalam memahami zat Allah yang sesuai dengan doktrin tradisionalis Sunni.

Tanggapan Mukhtār 'Ațārid memperlihatkan upaya dirinya untuk membersihkan ajaran tasawuf panteistik yang menganggap Tuhan dapat bersatu dengan manusia sehingga cenderung bertentangan dengan sifat mukhālafatuh ta'ālá li al-hawādith (berbedanya Allah Ta'ala dengan (makhluk-Nya) yang baru tersebut). Hal ini kiranya didasarkan pada sumber pokok ajaran tasawuf yang digunakannya, yaitu al-Ghazālī dan Junaid alBaghdādī yang menekankan pada aspek imanensi dan transendensi Tuhan sekaligus dalam suasana ketenangan batin tanpa

${ }^{62}$ Henry Corbin, History of Islamic Philosophy, Translated by Liadain Sherrard (London: Kegan Paul International and the Institute of Ismaili Studies, 1962), 116; M.M. Sharif, A History of Muslim Philosophy, Volume One (Wisbaden: Otto Harrassowitz-Wiesbaden, 1963), 226. 
harus mengalami ekstase (mabuk spiritual). Seorang mistikus dapat sangat dekat dengan Tuhan secara substansi dan kualitas dengan tetap membedakan di antara keduanya. ${ }^{63}$ Dengan kata lain, kedua ulama sufi tersebut menekankan pada ajaran tasawuf yang rekonsiliatif dan moderat, menolak panteisme dan mendamaikan antara hakikat dan syariat. Pandangan Mukhtār 'Ațāiid tersebut menjadi representasi pandangan ulama Nusantara di Mekah. Pandangan semacam ini kemudian umumnya dianut oleh para muridnya yang terhubung dengan jejaring intelektual Nusantara abad ke-20 hingga sekarang.

\section{Ajaran Tasawuf yang Benar}

Mukhtār 'Ațārid menganggap bidah tercela terhadap penyimpangan ajaran martabat tujuh, maka dalam kasus Ibn 'Arabī, Mukhtār 'Ațārid cenderung berusaha meluruskan kesalahpahaman orang terhadap ajarannya. Mukhtār 'Ațāid dalam kitab Kifāyah al-Mubtadi' 'in menganjurkan untuk berbaik sangka pada ajaran Ibn 'Arabī, karena diyakini merupakan ahli hakikat yang benar sesuai dengan syariat. Ia menganjurkan agar bersikap tawaqquf atau diam (sebelum ada petunjuk pengetahuan yang mendalam), tidak dibantah, karena terdapat maksud yang benar. Hal ini didasarkan pada keyakinannya bahwa kebanyakan orang tidak mampu meraih pemahaman tentangnya dengan benar. Bahkan para kekasih Allah (aulia) yang sedang majdhub (tidak sadar) sekalipun, maka wajib melakukan taslim (penerimaan) atas perbuatannya sepanjang tidak menyalahi aturan syariat. Sebuah pandangan arif dan didasarkan pengetahuan luas yang berbeda dengan pandangan kelompok Salafi/Wahabi yang menanggapi bidah terhadap ajaran tasawuf khususnya Ibn 'Arabī. Mukhtār 'Ațārid menyatakan:

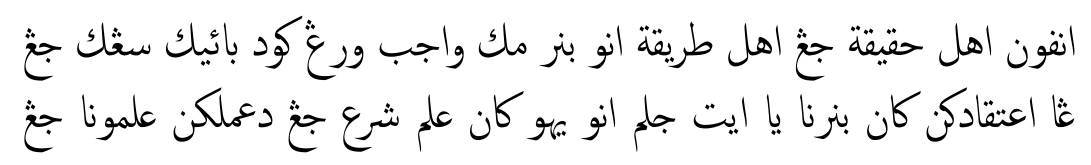

${ }^{63}$ M.M. Sharif, A History of Muslim Philosophy, 623; Alexander Knysh, Islamic Mysticism, A Short History (Leiden: Brill, 2000), 53. 


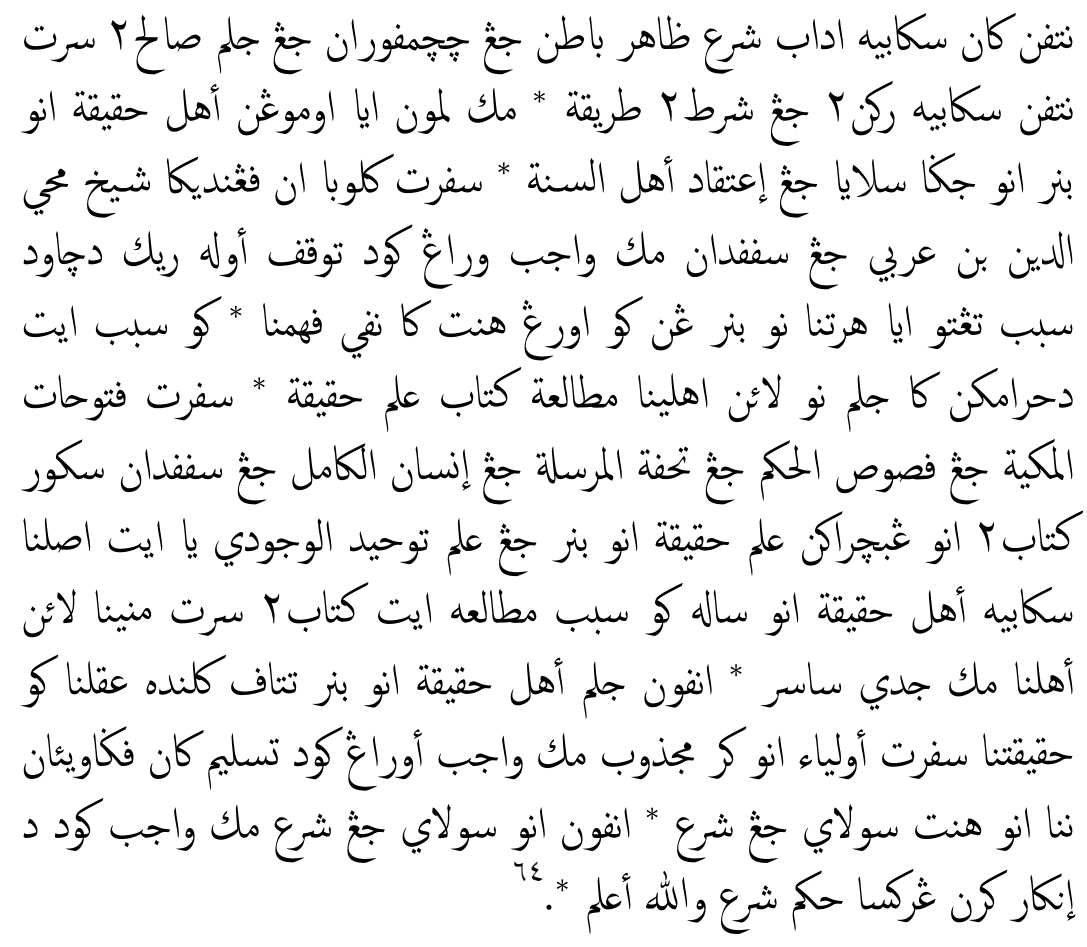

Anapon ahli hakekat jeung ahli tarekat anu bener maka wajib urang kudu baik sangka jeung ngaitikadkeun kana benerna nyaeta jalma anu nyaho kana elmu syara' jeung diamalkeun elmuna jeung netepna kana sakabeh adab syara' zahir batin jeung cacampuran jeung jalma-jalma soleh sarta netepna sakabeh rukun-rukun jeung sarat-sarat tarekat. Maka lamun aya omongan ahli hakekat anu bener anu jiga sulaya jeung itikad Ahlissunnah, saperti kalobaan pangandika Syekh Muhyiddin Ibn 'Arabi jeung sapapadana maka wajib urang kudu tawakup ulah rek dicawad sabab tangtu aya hartina nu bener ngan ku urang henteu ka tepi pahamna. Ku sabab eta diharamkeun ka jalma nu lain ahlina mutola'ah kitab elmu hakekat. Saperti Futuhat al-Makkiyyah jeung Fusus al-Hikam jeung Tuhfah al-Mursalah jeung Insan al-Kamil jeung sapapadana sakur kitab-kitab anu ngajarkeun elmu hakekat anu bener jeung elmu tauhid al-wujudi nyaeta aslina sakabeh ahli hakekat anu salah $k u$ sabab mutola'ah eta kitab-kitab sarta manehna lain ahlina maka

${ }^{64}$ Raden Al-Hāijj Muhammad Mukhtār bin Raden Natanagara, Kifāyah al-Mubtadi'in, 33-35. 
jadi sasar. Anapon jalma ahli hakekat anu bener tatapi kalindih akalna ku hakekatna saperti auliya anu keur majdhub maka wajib urang kudu taslim kana pagaweanana anu henteu sulaya jeung syara'. Anapon anu sulaya jeung syara' maka wajib kudu diingkar karana ngaruksa(k) hukum syara'. Wallahu a'lam.

Terjemahan:

Adapun ahli hakikat dan ahli tarekat yang benar, maka wajib kita berbaik sangka dan meyakini akan kebenarannya, yaitu orang yang mengetahui ilmu syariat, mengamalkan ilmunya, menetapkan semua adab syariat zahir-batin, bergaul dengan orang saleh dan menetapkan semua rukun dan syarat dalam tarekat. Maka, kalau ada ucapan ahli hakikat yang benar seperti menyalahi keyakinan ahlus sunnah, seperti kebanyakan ucapan Syekh Muhyī al-Dīn Ibn 'Arabī dan semisalnya, maka wajib kita harus tawaqquf (diam), jangan dibantah, sebab tentu ada maksudnya yang benar, tetapi oleh kita tidak sampai pemahamannya. Oleh sebab itu, diharamkan bagi orang yang bukan ahlinya untuk menelaah kitab ilmu hakikat, seperti Futūhāt al-Makkiyyah, Fuṣūs al-Hikam, Tuhfah alMursalah, al-Insān al-Kāmil dan semisalnya dari setiap kitab yang mengajarkan ilmu hakikat yang benar dan ilmu tauhīd al-wujūd. Asal mulanya semua ahli hakikat yang salah adalah karena sebab menelaah kitab-kitab itu dan karena dia bukan ahlinya, maka menjadi sesat. Adapun orang ahli hakikat yang benar dan tetap terkalah-kan akalnya oleh hakikatnya, seperti para aulia yang sedang majdhūb (tidak sadar), maka wajib kita harus taslìm (menerima) atas perbuatannya yang tidak menyalahi aturan syariat. Adapun yang menyalahi syariat, maka wajib harus ingkari, karena merusak hukum syariat. Wallāhu a 'lam.

Pernyataan tersebut menunjukkan bahwa Mukhtar 'Ațārid meyakini bahwa ajaran Ibn 'Arabī berada dalam koridor syariat. Tidak ada ajarannya yang menyimpang. Menurutnya, kebanyakan penilaian bidah dan sesat pada Ibn 'Arabī diberikan oleh orang yang tidak mampu memahami ajaran dan pemikirannya dengan baik atau bahkan disampaikan oleh orang yang bukan ahlinya. Karenanya, bagi Mukhtār 'Ațārid diharamkan bagi orang yang bukan ahlinya mempelajari kitab karangan Ibn 'Arabī seperti Futūḥāt al-Makkiyyah dan Fuṣūṣ al-Hikam. 
Demikian juga dengan karangan al-Burhānfūrī, Tuḩfah alMursalah ilá Rūh al-Nabī dan karya al-Jilī, al-Insān al-Kāmil fì Ma'rifah al-Awā'il wa al-Awākhir.

Pandangan Mukhtār 'Ațārid kiranya satu barisan dengan al-Kurānī, ulama Madinah abad ke-17, yang memberikan tanggapan dalam karyanya Ithaf al-Dhaki atas salah paham kaum Muslim Aceh terkait ajaran wahdatul wujūd (tauhīd al-wujūd) yang dibawa oleh Ibn 'Arabī. Al-Kurānī memberikan pembelaan sekaligus kompromi terhadap doktrin mistiko-filosofis Ibn 'Arabī. Ia menerima ajaran umum yang dikemukakan oleh para ulama Sunni dan memperluas cakupan maknanya hingga sejalan dengan tradisi sufi. Al-Kurānī, seperti terlihat juga pada Mukhtār 'Ațārid, mem-berikan koreksi atas pemahaman tasawuf heterodoks, panteistis dan dianggap mengesampingkan aspek-aspek syariat yang disebabkan salah paham terhadap doktirn-doktrin tasawuf yang terdapat dalam teks-teks tasawuf filosofis, seperti Tuhfah dan lainnya. ${ }^{65}$ Sebuah cara pandang tasawuf yang mengedepankan rekonsiliasi tasawuf dan syariat sebagai karakter khas ajaran tasawuf Sunni sebagaimana dianut oleh mayoritas kaum Muslim di Nusantara.

Kritik Mukhtār 'Ațārid terhadap penyimpangan ajaran martabat tujuh yang disebutnya dengan ilmu belewuk, ilmu payakinan atau ilmu alus, dengan demikian, harus dipahami dalam konteks kesalahpahaman kaum Muslim Nusantara terhadap ajaran itu yang dianggap mengabaikan syariat. Mukhtār 'Ațārid boleh jadi mengetahui berbagai cerita tentang penyimpangan ajaran martabat tujuh itu yang berkembang di kalangan ulama dan pelajar Nusantara di Mekah. Di sini Mukhtār 'Ațārid kemudian menyebut ajaran martabat tujuh sebagai ajaran menyimpang, meski yang dimaksudkannya adalah penyimpangan yang dilakukan oleh kaum Muslim Nusantara.

Penyebutan ajaran martabat tujuh sebagai ajaran menyimpang oleh Mukhtār 'Ațāiri juga didasarkan pada pilihan istilah yang digunakannya dalam menyebut ajaran itu dengan ajaran tauhīd al-wujūd berdasarkan sumber kitab yang dibacanya.

${ }^{65}$ Fathurahman, Ithaf Al-Dhaki, Tafsir Waḥdatul Wujūd Bagi Muslim Nusantara, 5-6. 
Karenanya, Mukhtār 'Ațārid tidak menyebut ajaran dalam kitab Tuhfah al-Mursalah karya al-Burhānfürī itu dengan martabat tujuh melainkan ajaran tauhīd al-wujūd. Karena baginya, istilah "martabat tujuh" cenderung dipahami sebagai ajaran yang menyimpang dari syariat sebagaimana banyak dipraktikkan kaum Muslim Nusantara.

Penggunaan istilah martabat tujuh sebagai ajaran menyimpang juga karena istilah "martabat tujuh" itu sendiri dianggap memiliki citra negatif di Timur Tengah. Pandangan negatif terhadap martabat tujuh yang berkembang di Mekah pada abad ke-19 misalnya, diceritakan oleh Syekh Daud Sunur (w. 1855), ulama pembaharu asal Minangkabau dalam Syair Rukun Haji yang ditulis tahun 1832. Menurutnya, saat itu ajaran martabat tujuh sudah dilarang di Mekah. Pelarangan itu disepakati oleh ulama Mekah-Madinah, Mesir dan Kufah. ${ }^{66}$ Situasi inilah yang membuat Mukhtār 'Ațārid juga memiliki pandangan yang sama, meski pada dasarnya ia sendiri lebih memilih menerima istilah tawhid al-wujud atau wahdah al-wujud yang diperkenalkan oleh Ibn 'Arabī, al-Jilī dan al-Burhānfūrī, bukan martabat tujuh.

Istilah martabat tujuh kemudian menjadi istilah yang umum digunakan di Nusantara untuk menyebut konsep tingkatan wujud tersebut dengan ragam modifikasi. Berbagai modifikasi yang diselaraskan dengan ajaran mistik Jawa yang dikenal dengan "sintesis mistis" membuat ajaran martabat tujuh menjadi berbeda dengan sumber dasarnya, Tuhfah al-Mursalah. Karenanya dapat dipahami bila kemudian Mukhtār 'Ațārid menganggap ajaran martabat tujuh itu dianggap menyimpang dari syariat.

Pandangan Mukhtār 'Ațārid tentang martabat tujuh pada dasarnya satu barisan dengan al-Kurān̄̄ yang lebih dulu memberikan tanggapan pada awal abad ke-17 terhadap kesalahpahaman kaum Muslim di Aceh terkait ajaran wahdatul wujūd dalam karya Ibn 'Arabī dan al-Burhānfūrī. Namun, dilihat dari konteks jaringan keilmuan Mukhtār 'Ațārid, sosok yang

${ }^{66}$ Suryadi, 'Syair Sunur: Autobiografi Seorang Dagang Minang-kabau', Sari, 23 (2005), 63. 
paling banyak berpengaruh terhadap pandangan Mukhtār 'Ațārid tentu saja adalah Sayyid 'Uthmān. Pengaruh gurunya di Batavia itu terhadap Mukhtār 'Ațārid jauh sebelum ia berangkat ke Mekah tahun 1903.

Sayyid 'Uthmān merupakan ulama keturunan Hadrami yang sangat keras terhadap tradisi tasawuf heterodoks yang berkembang di Nusantara. Ia menyusun dan mencetak karyakarya kritiknya dalam bahasa Arab, Melayu dan Sunda lalu disebarkan ke berbagai daerah di Nusantara. Kam-panye anti penyimpangan tarekat oleh Sayyid 'Uthmān sangat efektif. Ia mengambil strategi lebih modern dan praktis dengan membuat brosur pendek dan murah dengan bahasa yang tidak sulit sehingga bisa dipahami rakyat banyak. ${ }^{67} \mathrm{Hal}$ ini berbeda dengan Mukhtār 'Ațārid yang memilih jalan menggunakan jalur pendidikan dan mengarang kitab di Mekah untuk tingkatan khusus para elite agama, sehingga lebih terbatas. Daya kritis dan publikasi karya Sayyid 'Uthmān terhadap tasawuf heterodoks yang menyimpang dari syariat inilah kiranya berpengaruh terhadap diri Mukhtār 'Ațārid. Sehingga dapat dipahami bila pandangan Mukhtār 'Ațārid terhadap penyimpangan ajaran tasawuf heterodoks memiliki gagasan yang kurang lebih sama. Sebuah jejak intelektual keagamaan di dunia Melayu-Nusantara yang membentuk tradisi dan wacana keilmuan Islam sepanjang abad ke-17 dan terus berlangsung hingga sekarang.

\section{PENUTUP}

Kajian ini menunjukkan bahwa respons ulama Haramain terhadap wacana mistik Islam di Nusantara tidak hanya terjadi pada awal abad ke-17, tetapi terus berlanjut hingga awal abad ke20. Hal ini terlihat dari respons Mukhtār 'Ațārid, ulama Sunda yang menjadi pengajar di Mekah, yang menganggap bidah tercela terhadap penyimpangan ajaran martabat tujuh atau yang disebutnya sebagai ilmu belewuk di Nusantara. Tanggapannya dituangkan dalam dua buku berbahasa Sunda yang dicetak di Mesir, Kifāyah al-Mubtadi 'īn dan Hidāyah al-Mubtadi'n. Kajian ini menunjukkan bahwa tanggapan Mukhtār 'Ațārid men-

\footnotetext{
${ }^{67}$ Nico J.G. Kaptein, Islam, Colonialism, 193, 219.
} 
cerminkan kepentingan ortodoksi Sunni dalam bidang tasawuf yang bertumpu pada syariat, di tengah semakin derasnya tantangan terhadap tasawuf yang dibawa oleh kelompok Salafi/Wahabi di Mekah. Ia menyadari bahwa meski penguasa politik dan agama mengalami perubahan dan para ulama nonSalafi/Wahabi semakin tersingkir, tetapi warisan ortodoksi tasawuf Sunni perlu terus dijaga terutama bagi keberlangsungan identitas Islam yang terhubung antara Haramain dan Nusantara. Mukhtār 'Ațārid berusaha menunjukkan sikapnya sebagai penyokong ortodoksi tasawuf Sunni dengan cara meluruskan kesalahpahaman terhadap ajaran martabat tujuh dan para ulama tasawuf filosofiss seperti Ibn 'Arabī, al-Jilī dan al-Burhānfūrī. Penegasan sikapnya itu penting ditunjukkan di hadapan para pelajar Sunda di Mekah dalam konteks penguatan warisan tradisi intelektual Islam di Haramain yang membentang sejak abad ke17. Sikap dan pandangan Mukhtār 'Ațārid menunjukkan kearifan keberagamaan dalam melihat fenomena kontekstual pada zamannya. Ia berusaha mentransmisikan pendapatnya pada para muridnya melalui tradisi pendidikan keagamaan ke arah pembentukan ortodoksi tasawuf Sunni dan identitas Muslim Nusantara. Hal ini kiranya dapat dijadikan pembelajaran bagi diseminasi kesadaran keberagamaan saat sekarang dan masa mendatang.

\section{Ucapan Terima Kasih}

Penulis berterima kasih kepada kolega yang membantu kelancaran penulisan artikel ini. Alfan Khumaidi (Sewu Pengalem), mahamurid Mesir asal Indonesia yang dengan baik hati mengirimkan kitab cetak karya Mukhtār 'Ațārid. Ucapan terima kasih juga dihaturkan pada tim redaksi dan Mitra Bestari atas masukan dan saran untuk perbaikan artikel ini sehingga layak dipublikasikan.

\section{DAFTAR PUSTAKA}

\section{Buku}


Al-Attas, Syed Muhammad Naguib, The Mysticism of Hamzah Fanșūrī (Kuala Lumpur: University of Malaya Press, 1970).

Al-Falimbān̄̄, Muḥammad Mukhtār al-Dīn bin Zain al-'Ā'bidīn, Bulūgh Al-Amānī F̄̄ Al-Ta'rīf Bi Shuyūkh Wa Asānīd Musnid Al-'Așr Al-Shaikh Muhammad Yāsīn Bin Muhammad 'ì̄á Al-Fadan̄̄ Al-Makkī (Beirut: Dār Qutaibah, 1988).

Al-Ghazālī, Al-Imām Abī Ḥāmid Muḥammad bin Muḥammad bin Muḥammad, Bidāyah Al-Hidāyah (Beirut: Dār alMinhāj, 2004).

Al-Ghazālī, al-Imām Hujjah al-Islām Ab̄̄ Ḥāmid, Kitāb AlArba'īn Fì Ușūl Al-Dīn F̄̄ Al- 'Aqū 'Id Wa Asrār Al- 'Ibādāt Wa Al-Akhlāq (Damaskus: Dār al-Qalam, 2003).

Al-Jabbār, 'Umar 'Abd, Siyar Wa Tarājim Ba'd 'Ulamā'Inā F̄̄ Al-Qarn Al-Rābi' 'Ashr Li Al-Hijrah (Jeddah: Țuhāmah, 1982).

Al-Mar'ashlī, Yūsuf, Nathr Al-Jawāhir Wa Al-Durar F̄̄ 'Ulamā' Al-Qarn Al-Rābi' 'Ashar (Beirut: Dār al-Ma'rifah, 2006).

Al-Mar'ashlī, Yūsuf 'Abdurraḥmān, Mu'jam Al-Ma'ājim Wa AlMashīkhāt Wa Al-Fahāris Wa Al-Barāmij Wa Al-Athbāt, Vol. II (Riyad: Maktabah al-Rushd, 2002).

Al-Mu'allimī, 'Abdullāh bin 'Abdurraḥmān bin 'Abdurraḥ̄m, A'lām Al-Makkiyyīn Min Al-Qarn Al-Tāsi' Ilá Al-Qarn AlRābi' 'Ashar Al-Hijrī (Mekah: Mu'assasah al-Furqān li alTurāth al-Islāmī, 2000).

Al-Qurtuby, Sumanto, Saudi Arabia and Indonesian Networks, Migration, Education, and Islam (London: I.B. Tauris, 2020).

Al-Sanūsī, Rị̣ā' bin Muḥammad Șāfī al-Dīn, Dawr 'Ulamā' Makkah Al-Mukarramah F̄̄ Khidmah Al-Sunnah Wa AlSirah Al-Nabawiyyah (Madinah: Majma' al-Mulk Fahd li Ṭabā'ah al-Muṣhaf al-Sharīf bi al-Madīnah alMunawwarah). 
Al-Shāfi'̄i, Maḥmūd Sa'īd bin Muhammad Mamdūḥ, Tashnīf AlAsmā' Bi Shuyūkh Al-Ijāzah Wa Al-Simā', Vol. II (Beirut: Dār al-Kutub al-Mișriyyah, 1434).

Ali, Yunasril, Manusia Citra Ilahi, Pengembangan Konsep Insan Kamil Ibn 'Arabī Oleh Al-Jili (Jakarta: Paramadina, 1997).

Azra, Azyumardi, The Origins of Islamic Reformism in Southeast Asia: Networks of Malay-Indonesian and Middle Eastern 'Ulama' in the Seventeenth and Eighteenth Centuries (Honolulu: ASAA-Allen \& Unwin and University of Hawai'i Press, 2004).

Commins, David, The Wahhabi Mission and Saudi Arabia (London: I.B. Tauris, 2006).

Corbin, Henry, History of Islamic Philosophy, Translated by Liadain Sherrard (London: Kegan Paul International and the Institute of Ismaili Studies, 1962).

Dahīs, 'Abd al-Lațîf bin 'Abdullāh bin, Al-Hayāh Al-'Ilmiyyah Fī Makkah (1334-1115 H/1703-1916 M) (Mekah: Jāmi’ah Umm al-Qurá, 2006)

Fathurahman, Oman, Ithaf Al-Dhaki, Tafsir Wahdatul Wu.jūd Bagi MuslimNusantara (Bandung: Mizan, 2012).

— Tanbih Al-Masyi, Menyoal Wahdatul Wujūd Kasus Abdurrauf Singkel Di Aceh Abad 17 (Bandung: Mizan, 1999).

—, Tarekat Syattariyah Di Minangkabau (Jakarta: Prenada Media, EFEO, PPIM, KITLV, 2008).

Johns, A.H. The Gift Adressed to the Spirit of the Prophet (Canberra: Center of Oriental Studies A.N.U, 1965).

Kaptein, Nico, Muhimmāt Al-Nafā'is: A Bilingual Meccan Fatwa Collection for Indonesian Muslims from the End of the Nineteenth Century (Jakarta: INIS, 1997).

Kaptein, Nico J.G., Islam, Colonialism and the Modern Age in the Netherlands East Indies: A Biography of Sayyid 
'Uthmān (1822-1914) (Leiden: Brill, 2014).

Knysh, Alexander, Islamic Mysticism, A Short History (Leiden: Brill, 2000).

Kraus, Werner, 'The Shattariya Sufi Brotherhood in Aceh', in Aceh History, Politics and Culture, ed. by Arndt Graf Et.al (Singapore: Iseas, 2010).

Laffan, Michael, Islamic Nationhood and Colonial Indonesia, The Umma below the Winds (London: Routledge Curzon, 2003).

Lubis, Nina H., Kehidupan Kaum Menak Priangan 1800-1942 (Bandung: Pusat Informasi Kebudayaan Sunda, 1998).

Natanagara, Raden Al-Ḥājj Muhammad Mukhtār bin Raden, Kifāyah Al-Mubtadi'̄̄n Fī 'Ibādah Rabb Al-'Ālamīn (Kairo: Shirkah Maktabah wa Mațba'ah Mustafá al-Bābī al-Halabī wa Awlāduhu bi Miṣr, 1954).

Natanagara, Raden al-Hāijj Muḥammad Mukhtār bin Raden, Ieu Kitāb 'Aqū'Id Ahl Al-Sunnah Wa Al-Jamāa'ah (Mesir: Mustafá al-Bābī al-Ḥalab̄̄ wa Awlāduh bi Misr, 1341).

Natanagara, Raden Muhammad Mukhtār bin Raden, Hidāyah AlMubtadi 'īn Ilá Sulūk Maslak Al-Muttaqīn (Kairo: Mustafá al-Bābī al-Ḥalabī wa Awlāduh bi Mișr, 1346).

Ricklefs, M.C., Mengislamkan Jawa (terj. FX. Dono Sunardi dan Satrio Wahono, Jakarta: Serambi, 2013).

Rohmana, Jajang A, 'The Doctrin of Seven Grades in Hasan Mustapa's Verse', in Hasan Mustapa: Ethnicity and Islam in Indonesia, ed. by Julian Millie (Monash: Monash Publishing University, 2017), 117-140.

, Membekap Halilintar: Polemik Wahdatul Wujud Dalam Naskah Injāz al-Wa'd fi Itfā' al-Ra'd Karya Haji Hasan Mustapa (Garut: Layung, 2021).

Sharif, M.M., A History of Muslim Philosophy, Volume One (Wisbaden: Otto Harrassowitz-Wiesbaden, 1963). 
Shu'aib, Husain bin Muḥammad Hasan, Al-Dawr Al-Tarbaw̄̄ Li Halaqāt Al-'Ilm Bi Al-Masjid Al-Harām F̄̄ 'Abd Al-Mālik 'Abd Al-Azizz, Kulliyyah Al-Tarbiyyah Bi Makkah AlMukarramah (Mekah: Jāmi’ah Umm al-Qurá, 1428).

Steenbrink, Karel, Beberapa Aspek Tentang Islam Di Indonesia Abad Ke-19 (Jakarta: Bulan Bintang, 1984).

, 'Opposition to Islamic Mysticism in Nineteenth-Century Indonesia', in Islamic Mysticism Contested, Thirteen Centuries of Controversies and Polemics, ed. by Bernard Radtke, Frederick de Jong (Leiden-Boston: Brill, 1999), 687-703.

Taylor, Donald M. MacRaild dan Avram, Social Theory and Social History (New York: Palgrave MacMillan, 2004).

Trimingham, J. Spencer, The Sufi Orders in Islam (Oxford: Clarendon Press, 1977).

Wieringa, Edwin, 'Mecca Has Spoken, Case Closed: Muhammad Hasan B. Kasim's 1913 Meccan Poem of Advice on Sarekat Islam', in Contuinity and Change In The Realms Of Islam, ed. by J. Van Steenbergen K.D Hulster (Leuven: Peeters, 2008).

Zoetmulder, P.J., Manunggaling Kawula Gusti, Pantheisme Dan Monisme Dalam Sastra Suluk Jawa (terj. Dick Hartoko. Jakarta: Gramedia Pustaka Utama, 1991).

\section{Jurnal Ilmiah}

Christomy, Tommy, 'Shattariyah Tradition in West Java: The Case of Pamijahan', Studia Islamika, 8.2 (2001), 55-82.

Fathurahman, Oman, 'Ithaf Al-Dhaki by Ibrāhīm Al-Kurānī: A Commentary of Wahdat Al-Wujud for Jawi Audience', Archipel, 81 (2011), 177-98.

_, 'Sejarah Pengkafiran Dan Marginalisasi Paham Keagamaan Di Melayu Dan Jawa', Analisis, IX.2 (2011), 447-474. 
Johns, A.H., 'Islam in Southeast Asia: Reflections and New Directions', Indonesia, 19 (1975), 33-55.

Knysh, Alexander, 'Ibrāhīm Al-Kūrānī (d. 1101/1690), an Apologist for "wahdat Al-Wujūd"', Journal of the Royal Asiatic Society, 5.1 (1995), 39-47..

Meyer, Verena, 'Translating Divinity: Punning and Paradox in Hamzah Fansuri's Poetic Sufism', Indonesia and the Malay World, 47.139 (2019), 353-72

Rohmana, Jajang A., 'Sundanese Sufi Literature and Local Islamic Identity: A Contribution of Haji Hasan Mustapa's Dangding', Al-Jami'ah: Journal of Islamic Studies, 50.2 (2012), 303-327 $<$ https://doi.org/10. 14421/ajis.2012.502.303-327>.

, 'Authorship of The Jāwī "Ulamā" in Egypt: A Contribution of Nawawī Banten and Haji Hasan Mustapa to Sharh Tradition', Epistemé: Jurnal Pengembangan Ilmu Keislaman, 15.2 (2020), 221-64.

Soebardi, S., 'Santri-Religious Elements as Reflected in the Book of Centini', Bijdragen Tot de Taal-, Land-En Volkenkunde, 127.3 (1971), 331-349

Sunarwoto, 'Sheikh Mukhtār 'Ațārid on Belut', IJIPS, 6.1 (2012), 33-47.

Suryadi, 'Syair Sunur: Autobiografi Seorang Dagang Minang kabau', Sari, 23 (2005), 83-104.

Suryaningsih, Iin, 'Al-Haqiqah Al-Muwafaqah Li Al-Shari'ah: Al-Tasaluh Bayn Al-Tasawwuf Wa Al-Shari'ah Bi Nusantara Fi Al-Qarn Al-Sadis 'Ashr Al-Miladi', Studia Islamika, 20.1 (2013), 97-127.

Sya'ban, Ahmad Ginanjar, 'Al-Shaikh Mukhtār Bin 'Ațārid AlBūghūrī Al-Jāwī Thumma Al-Makkī (1862-1930) Wa AlKutub Al-Șundāwiyyah Al-Mațbū'Ah F̄̄ Makkah Wa AlQāhirah Awā'il Al-Qarn Al-'Ishrīn', Islam Nusantara, II.1 (2021), 93-112. 
_- 'Al-Syaikh Muhammad Mukhtār Bin 'Ațārid AlBughūrī Al-Jawi Thumma Al-Makki (1868-1930 M) Dan Jaringan Ulama Sunda Timur Tengah Awal Abad 20 M', International Journal of Pegon, 1.1 (2018), 39-62.

Yunus, Abdul Rahim, 'Nazariyat Martabat Tujuh Fi Nizam AlMamlakah Al-Butaniyyah', Studia Islamika, 2.1 (1995), 93-110.

\section{Disertasi}

Basri, Indonesian 'Ulama $\bar{a}$ ' in the Haramayn and the Transmission of Reformist Islam in Indonesia (1800-1900) (Ph.D. Dissertation: University of Arkansas, 2008). 
Jurnal Lektur Keagamaan, Vol. 19, No. 1, 2021: 1 - 36

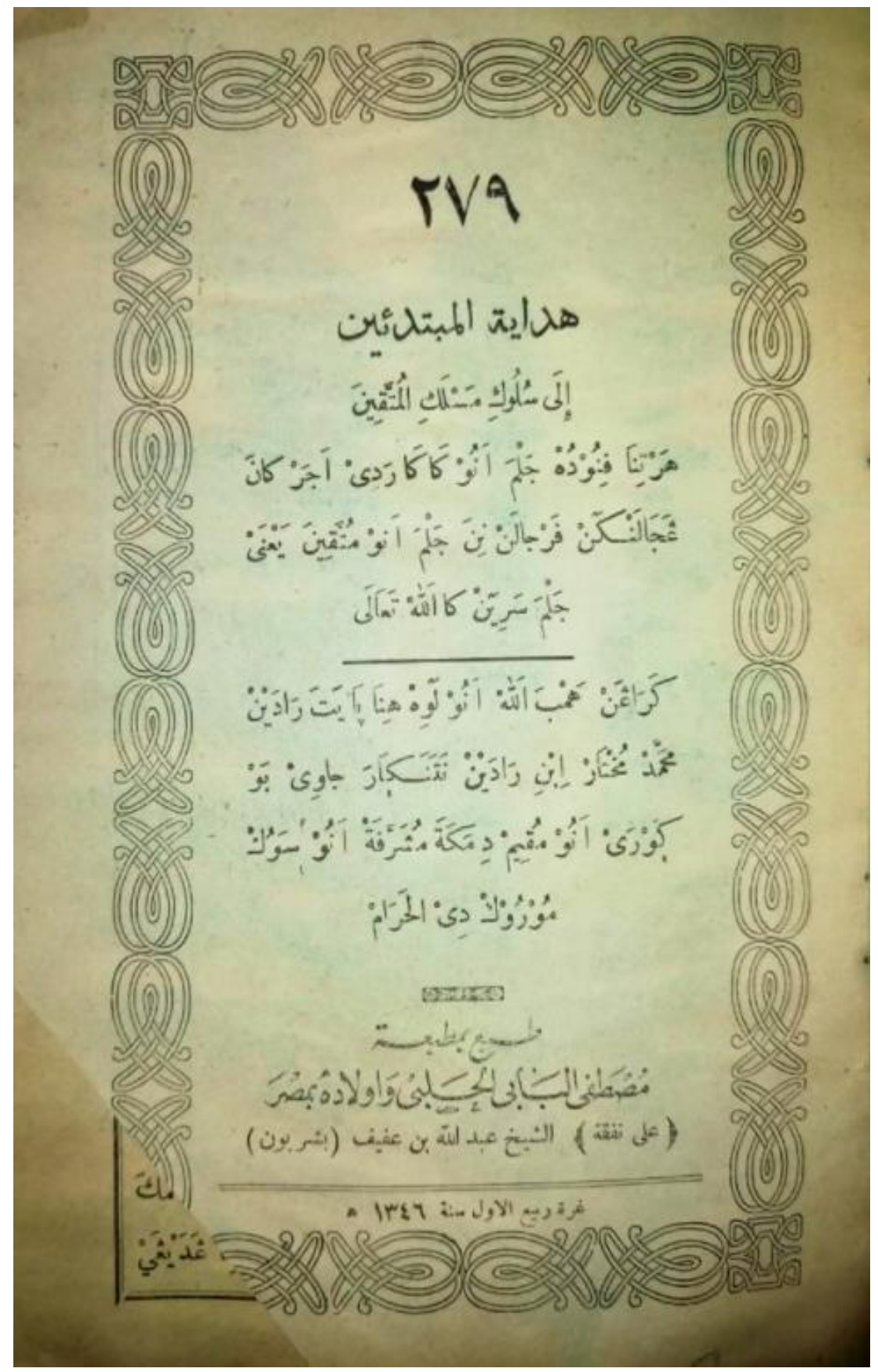

